\title{
Corticosteroids: Sculptors of the Hippocampal Formation
}

\author{
Nuno Sousa ${ }^{1,2}$ and Osborne F.X. Almeida ${ }^{3}$ \\ 'Department of Anatomy, Porto Medical School, Porto, Portugal, \\ ${ }^{2}$ Life and Health Sciences Research Institute, University of Minho, Braga, Portugal and \\ ${ }^{3}$ Max-Planck Institute for Psychiatry, Munich, Germany
}

\section{CONTENTS}

\section{Synopsis}

1. Introduction

2. Corticosteroids and their receptors

3. Broad overview of the cerebral actions of corticosteroids

4. Major biochemical substrates mediating corticosteroid actions on hippocampal structure and function

5. Critical analysis of observations ascribing hippocampal cell death to alterations in the corticosteroid milieu

6. Corticosteroids and fine structural changes in the hippocampal formation

7. Corticosteroids and neuronal birth in the dentate gyrus

8. Conclusions

Acknowledgements

References

Accepted: 13 December, 2001

Reprint address:

Nuno Sousa

Instituto de Ciências da Vida e da Saúde

Escola de Ciências da Saúde

University of Minho

Campus de Gualtar, CP II, Piso 3

4710-057 Braga, Portugal

e-mail:njcsousa@ecsaude.uminho.pt

\section{SYNOPSIS}

The influence of corticosteroids on hippocampus-dependent learning and memory processes is now indisputable. On the other hand, closer scrutiny of early studies together with interpretations from newer studies would suggest that the proposition that corticosteroidinduced hippocampal cell death accounts fully for the associated cognitive deficits is only partially correct. Firstly, it is now clear that a specific sub-population of hippocampal neurons, the granule cells of the dentate gyrus, is more sensitive to changes in the corticosteroid environment; this fact raises the interesting question of what might be the unique properties of granule cells that render them more vulnerable to these hormones, since virtually all hippo-

\footnotetext{
Abbreviations:

ACTH: adrenocorticotropin hormone; ADX: adrenalectomy; ALDO: aldosterone; AP-1: activator protein 1; BDNF: brainderived growth factor; bFGF: basic fibroblast growth factor; bFGF-R: basic fibroblast growth factor receptor; $\mathrm{CAl}$ and CA3: fields of hippocampus; CORT: corticosterone; CRF: corticotropin-releasing factor; DEX: dexamethasone; DST: dexamethasone suppression test; GLUT: glucose transporters; GR: glucocorticoid receptor or type II receptor; HPA: hypothalamo-pituitary-adrenal; HRE: hormone responsive elements; 5-HT: 5-hydroxytryptamine or serotonin; IGF-I: insulin growth factor-I; LTD: long-term depression; LTP: longterm potentiation; MAP kinase: mitogen-activated kinase; MFCA3: mossy fiber-CA3; MR: mineralocorticoid receptor or type I receptor; MRI: magnetic resonance imaging; NF-KB: nuclear factor $\mathrm{\kappa B}$; NGF: nerve growth factor; NMDA: $N$ methyl-D-aspartate; NOS: nitric oxide synthase; NR2A and NR2B: subunits of NMDA receptors; NT3 and NT4/5: neurotrophins; p75NTR: p75 neurotrophin receptor; PBP: primed-burst potentiation; PI3-kinase: phosphatidylinositol 3kinase; PKB/Akt: protein kinase B; PTSD: post-traumatic stress disorder; ROS: reactive oxygen species; Trk: tyrosine kinase; TUNEL: terminal transferase-mediated dUTP-biotin nick end labeling.
} 
campal cells express corticosteroid receptors. Secondly, from a critical analysis of the available data, the picture that emerges is that corticosteroids, by acting through two distinct receptors, influence not only cell birth and death, but probably also cell differentiation. Mineralocorticoid receptor (MR) occupation appears to be essential for the survival of existing and newly generated granule neurons. In contrast, while glucocorticoid receptors (GR) can induce loss of neurons in the absence of MR activation, it appears that their occupation usually results in less drastic effects involving only dendritic atrophy and loss of synaptic contacts. This revised scheme of corticosteroid actions on hippocampal structure should explain earlier observations that many of the cognitionimpairing effects of corticosteroids are reversible.

\section{KEY WORDS}

corticosteroids, hippocampus, stress, granule cells, dentate gyrus, cell birth, apoptosis, differentiation, mineralocorticoid receptors, glucocorticoid receptors, cognitive effects

\section{INTRODUCTION}

Investigating the actions of corticosteroids in the hippocampus has occupied a large number of neurobiologists over the last decade, with impetus for interest and activity in this area stemming from the descriptions by Aus der Muhlen and Ockenfels $/ 10 /$ that pharmacological doses of hydrocortisone lead to degeneration of hippocampal pyramidal cells in the guinea-pig and Philip Landfield's laboratory /105/ that plasma corticosterone levels and adrenal weight are positively correlated with hippocampal aging, as measured by astrocyte hypertrophy in the rat. Landfield et al. /103/ also showed that elimination of circulating glucocorticoids (by adrenalectomy [ADX]) in young adult rats prevented neuronal loss during senescence. Seminal reviews by Munck et al. $/ 150 /$ and Sapolsky et al. /187/, which revitalized interest and inspired closer examination of Hans Selye's
'General Adaptation Syndrome' and the pathophysiological role of glucocorticoids (for a review see McEwen /130/), also played no small part in generating research into how adrenocortical secretions influence hippocampal structure and function.

A commentary in 1996 by Sapolsky in Science /184/, entitled 'Why stress is bad for your brain', probably best sums up the negative view in most people's minds about the effects of glucocorticoids on the hippocampus, a brain area implicated in the regulation of a number of behavioral and neuroendocrine functions. As emphasized below, the stress response per se is good for the organism; however, as pointed out by numerous authors (see Munck et al. /150/ and Sapolsky et al. /187/), the inability to adapt to a stressor can lead to deleterious effects in the hippocampus and the organism as a whole. It also needs to be remembered that the stress response involves myriad neurochemical changes besides the wellknown alterations in glucocorticoid secretion. In fact, glucocorticoids or, more correctly, corticosteroids, which signal through at least two distinct nuclear receptors, have the potential to exert different actions, a concept embodied in de Kloet's 'pendulum hypothesis' /40/ and the review by de Kloet et al. entitled 'Stress and cognition: Are corticosteroids good or bad guys?' /41/.

It is fitting to state at the outset that, although increased adrenocortical activity is part of the stress response, the mere elevation of plasma levels of corticosteroid hormones (e.g. pharmacologically) does not produce a state equivalent to stress. The term 'stress' in fact refers to the organism's attempt to mount an 'adaptive' (beneficial) response to aversive stimuli in order to maintain or restore homeostasis. Different sensory and motor systems will be differentially activated depending on the quality and intensity of stressful (aversive) stimuli, and the magnitude and duration of the stress response will be influenced by the 'context' of the stimulus (experience, mood, age, environmental factors). Thus, extreme caution is necessary before generalizing about the effects of one particular 'stress'.

Since stress elicits primarily adaptive responses, it cannot be harmful. On the other hand, as recognized by Selye /193/ and noted above, in the 
event that adequate adaptive mechanisms cannot be recruited, chronic stress will result in a state of chronic hypercorticalism and deleterious effects, including immune suppression and a variety of mental disturbances $/ 11,76,77,133,235 /$. Indeed, it has been argued that stress is detrimental for the brain on the basis of observations that patients with Cushing's syndrome /207,208/ or major depression /24,195/ have significantly reduced hippocampal volumes which correlate negatively with corticosteroid exposure. In addition, the size of the hippocampus is reduced in individuals suffering from post-traumatic stress disorder (PTSD) $/ 25 /$. At best, the examples cited provide only correlative evidence for a causal role of corticosteroids in reduced hippocampal size, and a valid criticism that may be leveled against these studies is that they all employed magnetic resonance imaging (MRI) techniques, which do not (yet) permit definitive differentiation between cellular and extracellular fluid volumes. Nevertheless, it should be mentioned that other studies have shown an association between cognitive impairment and reduced hippocampal volumes $/ 46,66,173 /$, the latter correlating with high circulating corticosteroid levels $/ 117,118$, 151/. Perhaps the data from patients with PTSD represent the most intriguing of the abovementioned examples. Some time after exposure to the triggering traumatic stimulus, these individuals develop hypocortisolemia $/ 238,239 /$. While it has been proposed that the initial stress-associated hypersecretion of corticosteroids is most probably responsible for the lasting detrimental effects on hippocampal size, this reasoning is difficult to reconcile with the well-documented reversibility of high corticosteroid effects on hippocampal volume and cognition after surgical or pharmacological treatment of patients with Cushing's syndrome $1208 /$ in whom the duration of exposure to supraphysiological levels of cortisol would be expected to be much greater than in patients with PTSD. A reappraisal of these findings, in testable animal models and in the context of the sensory and, ultimately, neurochemical inputs upon exposure to stress, can be expected to help resolve this apparent enigma.

To bring the present state of knowledge into perspective, and hopefully to identify issues still to be clarified, this article attempts to review critically the neuroanatomical and pharmacological specificity of corticosteroid actions in the hippocampus and their possible functional significance. In addition to discussing issues that may help resolve questions relating to the interpretation of published studies on corticosteroid effects upon hippocampal cell survival and plasticity, we also discuss the role of corticosteroids in hippocampal cell birth (neurogenesis), a field pioneered by Elisabeth Gould, Bruce McEwen and colleagues. Neurogenesis represents a challenging part of modern neurobiology not only because one intuitively thinks that more neurons contribute to a 'better brain', but also because cell death and birth, together with cell differentiation and plasticity (neurochemical, morphological and electrophysiological), are all inter-related and constitute essential processes in the life of a cell.

\section{CORTICOSTEROIDS AND THEIR RECEPTORS}

The adrenal gland, first described by Bartholomaeus Eustachius in 1563, is the source of the principal corticosteroids, namely cortisol, corticosterone and aldosterone. Like all other steroid hormones, these small molecules (typically ca. $300 \mathrm{Da}$ ) are derived from cholesterol and pregnenolone following a series of enzymatic conversions $/ 7 /$. The synthesis and secretion of cortisol (the predominant adrenocortical hormone found in humans and most other mammals) and corticosterone (principal adrenocorticoid in rodents and lagomorphs) is governed by adrenocorticotropin hormone (ACTH), released from the anterior pituitary, which in turn is controlled by hypothalamic corticotropin-releasing factor(s) (CRF) /234/. This top-down control of adrenocortical function is complemented by negative feedback mechanisms exerted by corticosteroids via corticosteroid receptors at the pituitary and hypothalamic levels $/ 73,234 /$, but also at the level of the hippocampus $/ 74,82,95,96 /$. The experience of a stressful stimulus leads to increased CRF-ACTHcorticosteroid secretion, thereby restoring homeostasis. The threshold of the stress response may vary with age, as indicated by the higher and prolonged hormonal responses observed in many 
aged individuals $/ 81,146 /$, the latter changes being ascribed to impaired negative feedback mechanisms $/ 49,81,146 /$. It is relevant to point out that, contrary to the widely-held view, aged subjects do not apparently secrete more corticosterone under basal conditions, as revealed by systematic analyses in humans $/ 126 /$, non-human primates $/ 224 /$ and rodents $/ 70 \%$. Also important to mention within the framework of this review are reports of causal associations between increased adrenocortical activity and cognitive and mood disorders $/ 11,76$, $117,118,130,135,235 /$. As discussed below, it still remains to be established whether the changes in corticosteroid levels are causal, consequential or simply secondary events in these pathological states.

Being small lipophilic molecules, corticosteroids can access the brain /136/. Administration of radioactively-labeled corticosteroids resulted in brain area-selective retention of label, with the highest signal being found in the hippocampus (see McEwen et al. /134/ for a review). In a landmark study on the rat brain, Reul and de Kloet /174/ reported that corticosterone binds with different affinities to two different receptors; they showed that a subpopulation of receptors, predominantly found in the septum and hippocampus, demonstrated a higher affinity (6-10 fold more) for corticosterone. Subsequent cloning studies revealed full homologies between the high affinity and low affinity central corticosteroid receptors and peripheral mineralocorticoid (MR) and glucocorticoid (GR) receptors, respectively $/ 8,75 /$. In vitro studies showed that the high affinity binding site in brain can bind aldosterone, suggesting that central MR might be activated by either corticosterone or aldosterone /174/. However, as revealed by Funder $/ 55 /$, the endogenous production of aldosterone only provides sufficient concentrations of this ligand in the vicinity of renal MR; thus, the 'promiscuous' behavior of cerebral MR is determined by ligand availability rather than tissue selectivity. To embrace this subtle, but fundamental difference - one ligand, two receptors - the terms type I corticosteroid receptor and type II corticosteroid receptor were suggested as more appropriate descriptors of central MR and GR, respectively 199/. Our current understanding of the actions mediated by the two receptors has been aided by exploiting the high selectivity of aldosterone for the MR and dexamethasone (DEX) and RU28362 for the GR, and antagonists such as spironolactone or RU28318 (MR) and RU38486 (GR). Further insights into the biological actions of MR and GR are beginning to be gained from various $M R$ and GR gain- and loss-of-function mouse models $/ 106,112,172 /$.

The differing affinities of the two corticosteroid receptors means that MR are predominantly occupied during periods when corticosteroid levels are low, whereas GR only become occupied when corticosteroid secretion increases above a certain threshold (e.g. during stress or in pathological conditions) $/ 40,84,85,174 /$. The pharmacological binding properties of cerebral MR and GR for endogenous ligands, such as corticosterone, may be important for the interpretation of experimental results emerging from experiments in which hormone supplementation may result in gradual increases in ligand availability (e.g. see Sousa et al. /204/). Such considerations must also be kept in mind, of course, when the effects of commonlyused therapeutic corticosteroids (e.g. prednisone which shows affinity for both receptors) are being studied. At this stage, it is also pertinent to mention the demonstration of a highly effective biochemical mechanism that can prevent excessive stimulation of GR /192/. These authors have clearly demonstrated that the enzyme $11 \beta$-hydroxysteroid dehydrogenase (11ß-HSD) type 1 increases local glucocorticoid concentrations in several brain areas, including the hippocampus, while $11 \beta$-HSD type 2 can convert potent glucocorticoids to weaker or inactive forms.

Like other members of the steroid-thyroid hormone receptor family, MR and GR are ligandregulated transcription factors. Since their cloning $18,75,161$, our knowledge about their structure, distribution, and signaling modes has grown considerably. GR are widely distributed throughout the brain, but are particularly concentrated in the hippocampus, hypothalamus and lower brainstem $12,34,56 /$. MR are almost exclusively confined to the hippocampus and other limbic structures, such as the septum, medial amygdala, the olfactory nucleus and some hypothalamic nuclei $/ 3,222 \%$. 
Within the hippocampal formation, subfieldspecific differences in MR and GR concentration profiles have been described: MR levels are high in CAl pyramidal layer $\approx$ granule cell layer (dentate gyrus) $>\mathrm{CA} 3$ pyramidal layer, and $\mathrm{GR}$ are concentrated in the $\mathrm{CA} 1 \approx$ dentate gyrus $\gg \mathrm{CA} 3$ $/ 147,174,222 /$. The functional significance, if any, of these differential patterns of receptor distribution may be inferred from the known functions of the particular brain nuclei displaying high levels of MR and GR expression and/or ligand binding. The fact that high receptor densities occur in brain regions serving as 'sensors' and 'pacemakers' within neural circuits controlling the transduction of adrenosteroid signals into behavioral responses (hypothalamus and septo-hippocampal complex) and, at the same time, those brain areas which store and compare the cognitive-emotional context of environmental stimuli (amygdala, septo-hippocampal complex), cannot be ignored. Integration of information within these circuits most probably contributes to 'decisions' about the appropriate amplitude and duration of pituitary-adrenal and behavioral responses to a particular homeostatic threat. At this juncture, it may be important to point out that while the described patterns of MR and GR occurrence in the various hippocampal subdivisions may serve as eventual predictors of function, they do not necessarily reflect the receptor repertoire of individual cells in any region; furthermore, it is still not known as to what extent receptor composition (concentration of individual receptors or colocalization of MR and GR in the same cell) determines the fate of a particular cell to changes in the corticosteroid milieu.

Agonist occupation leads to GR translocation from the cytoplasm to the nuclear compartment 1216/. Heat shock (or chaperone) proteins such as hsp90 and hsp56 help to retain unbound GR in the cytoplasm and, at the same time, appear to contribute to the receptor's high affinity for ligand $152,164 /$. Less is known about the activation and dynamics of MR; however, immunolocalization studies indicate that MR may be present in both cytoplasmic and nuclear compartments, even in the absence of ligand $/ 113,154 /$. As is the case for other nuclear receptors, MR and GR form (homo)dimers before attachment to specific palindromic DNA sequences (hormone response elements [HRE]) /17, $52,92,124,216 /$. However, MR-GR heterodimerization has also been reported, thus increasing the spectrum of potential transcriptional events 132 , 213,214/. Binding of receptor dimers to the HRE represents only a first step in the transcriptional processes initiated by ligand-dependent transcriptional factors such as GR and MR. As described in several reviews $/ 17,52,216,241 /$, these processes are governed by numerous factors including the numeric presence of HRE, spatial relationships between the HRE and relevant promoters on the corresponding gene(s), the interposition of various components of the transcription initiation complex, and interactions with a host of general and intermediary transcription factors (co-activators and co-repressors). Moreover, the ability of at least the GR to influence the transcriptional activity of other transcription factors, such as activator protein 1

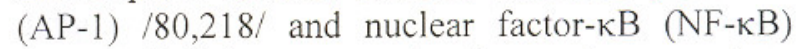
$/ 12,219,220 /$ by trans-activation and -repression, allows corticosteroid receptors to influence genes which lack a cognate HRE. In addition, it should be noted that although corticosteroids are best known in their role as modulators of genomic function, there is growing evidence that these steroids may also alter cellular activity by acting at membranebound receptors /123/. The intracellular signal transduction pathways involved in membranemediated corticosteroid actions are just beginning to be described; recent studies suggest the involvement of mitogen-activated kinase (MAP kinase) cascades $/ 110 /$.

\section{BROAD OVERVIEW OF THE CEREBRAL ACTIONS OF CORTICOSTEROIDS}

Thomas Addison's studies in humans (1855) and those by Charles Brown-Séquard in animals (1856) demonstrated the indispensability of the adrenal glands for survival. Describing the now rare condition of adrenal insufficiency (Addison's disease), Addison noted an association between a variety of metabolic symptoms, including some involving brain dysfunction, e.g. anorexia, nausea, amenorrhea and loss of libido, and apathy. Later, Walter Cannon's (1939) introduction of the concept of homeostasis provided a better appreciation of the 
broader physiological significance of corticosteroids. It is of relevance to note here that Sloviter and colleagues showed in 1989 that ADX in rats, an experimental model closely resembling Addison's disease, results in a marked loss of granule cells in the dentate gyrus of the hippocampus /198/. Indeed, loss of granule cells has also been reported in a case of untreated Addison's disease $/ 119 /$.

Evidence for adrenocortical hormone influences on brain function is provided by another, albeit opposite, experiment of nature. In Cushing's disease (first described by William Cushing in 1932), corticosteroid hypersecretion occurs secondary to an ACTH-producing pituitary tumor (adenoma). Neuropsychological testing in patients with this ailment show impaired cognition but the impairment can be reversed upon chemical inhibition or surgical removal of the tumor $/ 208 /$. Philip Hench's (1950) Nobel Prize-winning observations on the anti-inflammatory actions of corticosteroids heralded the still-reigning era of synthetic corticosteroids in the treatment of autoimmune and inflammatory and certain oncological diseases. The over-zealous application of corticosteroids in these conditions results in Cushing's syndrome, which may include severe metabolic and behavioral disorders $/ 27,200,235 /$. There is now considerable experimental evidence that exposure to elevated corticosteroid levels can influence reproductive behavior and hormone secretion, mood, learning and memory, as well as hippocampal cell birth and survival; in humans, the last has been inferred from gross changes in hippocampal volume as measured by MRI /117,118,235/.

Bi-directional influences of corticosteroids and stress on cognition are well recognized $/ 41,135 /$. Thus, in both experimental animals and humans, acute instances of emotional arousal or stress enhance memory processes, while prolonged stimuli lead to an impairment of cognitive performance. A number of studies have shown that MR and GR exert specific and independent actions on cognition, and further that improved cognitive performance relies on the appropriate balance of MR and GR activation /41/. Thus, while MR activation appears to be important for the acquisition of information about novel stimuli as well as for the recruitment of appropriate behavioral responses to a particular stimulus, GR activation seems to play a crucial role in memory consolidation /155-157/. Importantly, however, supplementary activation of GR by stimuli that remain outside the scope of an appropriate behavioral response can impair the consolidation process $/ 179,180 /$. These learning/memory processes have well-characterized electrophysiological correlates $/ 16,20,21 /$, and their modulation by corticosteroids may not be surprising in light of the ability of corticosteroids to influence neuronal membrane potentials /84/.

Corticosteroids produce biphasic effects on long-term potentiation (LTP) and primed-burst potentiation (PBP) as well as on long-term depression (LTD) in the hippocampus. LTP represents the electrophysiological correlate of synaptic reinforcement, whereas LTD is thought to represent an opposite phenomenon /16,20,21/. Maximal LTP induction is observed during MR occupation $/ 43,162,175 /$. In contrast, when MR are unoccupied (e.g. in the ADX state) or when GR are stimulated (e.g. during stress), there is a marked impoverishment of LTP in favor of LTD /37,43/. In summary, whereas stress-induced levels of adrenal steroids inhibit LTP, lower concentrations of the hormone, such as those observed under basal conditions, enhance plasticity. From the preceding, it thus emerges that corticosteroids may play the role of 'double agents' or 'good guys and bad guys' in the hippocampus. The duality of corticosteroid receptors is pivotal to our understanding of the role of corticosteroids in the physiology and pathology of the brain.

\section{MAJOR BIOCHEMICAL SUBSTRATES MEDIATING CORTICOSTEROID ACTIONS ON HIPPOCAMPAL STRUCTURE AND FUNCTION}

Over the years, a number of neurobiochemical events have been suggested to mediate corticosteroid effects in the brain. Here, we focus on those changes which may have an impact on the morphology of the various hippocampal subfields, and subsequently on hippocampal function. Prominent among the proposed mechanisms is the ability of corticosteroids (glucocorticoids) to modulate 
glucose uptake /183/. Energy supply is an important issue since neurons are particularly vulnerable to energy crises due to their limited energy storage capacity. Deprivation of glucocorticoids by ADX increases glucose utilization /87/ and, simultaneously, increases cerebral blood flow $/ 50 /$, with a concomitant decrease in cerebral glucogenesis /163/. On the other hand, elevated glucocorticoid levels reduce glucose availability to neurons $/ 45 /$, most probably due to GR-mediated changes in the expression of glucose transporters in the bloodbrain barrier (GLUT-1) and neuronal membranes (GLUT-3) /78,168,183/. Recent studies by Reagan et al. /169/ have shown that GLUT-3 activity decreases during stress, an event accompanied by high glucocorticoid secretion, increased lipid peroxidation and an accumulation of hydroxynonenal; upon conjugation with GLUT-3, hydroxynonenal carries GLUT-3 to the neuronal cytoplasm, thus impairing glucose uptake processes at the cell membrane. Energy crises produced in this manner have been proposed to play a significant role in making neurons more vulnerable to other insults, such as excitotoxins and reactive oxygen species (ROS) $/ 170,183 /$.

Corticosteroids have also been described to exert an influence over the synthesis of several neurotransmitters and the density and/or signaling efficiency of neurotransmitter receptors of particular interest to the central theme of this review (see $/ 83,84,183 /$ ). For example, high corticosteroid levels exacerbate the toxicity of glutamate, the primary excitatory neurotransmitter in the CNS $/ 188,210 /$. Since energy-dependent glutamate transporters represent the main mechanism by which glutamate activity can be terminated (via astrocytic uptake) at the postsynaptic site $/ 226 /$, any energy deficit (e.g. as a result of excessive glucocorticoid levels) will result in an accumulation of glutamate within the neuron. This leads to the triggering of a neuro-excitotoxic cascade (increased intracellular $\mathrm{Ca}^{2+}$ levels, leading to a stimulation of proteases, nucleases and lipases, as well as of nitric oxide synthase which leads to the generation of nitric oxide-derived free radicals) $/ 47,170,183 /$. Such events have been indicated to occur during stressassociated cytoskeletal damage and neuronal atrophy, the latter effects being diminished by the application of excitatory amino acid antagonists $/ 120,131 /$. In further support of the involvement of glutamate in stress-induced changes in the hippocampal formation, recent studies /60,61/ have shown that blockade of $N$-methyl-D-aspartate (NMDA) receptors disinhibits the reduction of neurogenesis in the hippocampus seen after stress (high corticosteroid secretion).

Alterations of the corticosteroid milieu also influence glutamatergic transmission through other mechanisms. For example, Doi et al. /44/ showed that excitability in the glutamatergic Schaffer collaterals (which project from the CA3 to CA1 pyramidal fields in the hippocampus) is attenuated by $\mathrm{ADX}$ in a corticosterone-reversible manner. These results are supported by other studies which report that high levels of corticosteroids increase /209/, whereas ADX decreases /115,145/, basal and kainic acid-induced glutamate concentrations in the hippocampus. Furthermore, chronic exposure to glucocorticoids has been shown to influence the expression of NMDA receptor subunits (NR2A and NR2B subunits) in the hippocampus $/ 232 /$. Hippocampal kainate receptors, which stimulate glutamate release and are located at presynaptic terminals of the mossy fibers which project from granule cells to the $\mathrm{CA} 3$ area, are also subject to upregulation by corticosteroids and downregulation by ADX $/ 231 /$.

Besides the above-mentioned role of $\mathrm{Ca}^{2+}$ in the glutamatergic-induced excitotoxic cascade, experimental evidence also suggests that glucocorticoids may per se enhance the postsynaptic $\mathrm{Ca}^{2+}$ tone by influencing phosphoinositide metabolism and, therefore, the mobilization of intracellular $\mathrm{Ca}^{2+}$ stores /98/. Apart from these alterations in the postsynaptic $\mathrm{Ca}^{2+}$ tone, it is important to mention that an important aspect of corticosteroid actions in the hippocampus involves the ability of adrenal corticosteroids to modulate voltage-gated $\mathrm{Ca}^{2+}$ currents in dentate granule and CA1 hippocampal neurons $/ 83,90,91 /$. Alterations in $\mathrm{Ca}^{2+}$ flux have been suggested to contribute to the vulnerability of granule cells to undergo apoptosis after variations in the corticosteroid milieu /90/. However, it is difficult to reconcile these changes in $\mathrm{Ca}^{2+}$ currents (which are similar in dentate granule and CAl pyramidal cells) with the different vulnerability of 
these neuronal populations to death.

Reactive oxygen species (ROS, or free radicals), well known for their potential to cause lipid peroxidation and/or DNA damage, have been amply implicated in neuronal cell death, and glucocorticoids have been demonstrated to amplify ROSinduced cell death $/ 19,139 /$. The latter has been proposed to result from the ability of glucocorticoids to decrease neuronal defenses against oxidative stress, e.g. by inhibiting the activity of the anti-oxidant enzymes superoxide dismutase, catalase and glutathione peroxidase $/ 137,138 /$. In addition, there is evidence suggesting that glucocorticoids themselves may lead to increased ROS generation $/ 138,139 /$, most probably due to the accumulation of high intracellular $\mathrm{Ca}^{2+}$ levels. The latter may include activation of nitric oxide synthase (NOS), and thus the production of a series of $\operatorname{ROS} / 29,159 /$. However, it should be noted that this latter mechanism is still contentious insofar as some authors claim that glucocorticoids inhibit NOS activity in the hippocampus $/ 114,171 /$.

A number of growth factors have been implicated as targets of corticosteroids. These include the neurotrophins (nerve growth factor $[\mathrm{NGF}]$, brainderived nerve growth factor [BDNF], neurotrophin 3 [NT3], and neurotrophin 4/5 [NT4/5]), all of which are associated with either neuronal survival or plasticity, including learning and memory (see $/ 109,111,127,189,211 /$ for review). The neurotrophins signal through one or more tyrosine kinase (Trk) receptors, namely TrkA receptors (NGF and to a lesser extent, NT3), TrkB receptors (BDNF and NT4/5) and TrkC receptors (NT3). In contrast with these high-affinity neurotrophin receptors, all neurotrophins also bind to the p75 neurotrophin receptor (p75NTR). This low affinity receptor can paradoxically induce apoptosis, a property most likely related to the fact that p75NTR contains an intranuclear domain which shows significant homology with the 'death domain' of other members of the tumor necrosis factor family to which p75NTR itself belongs $/ 31,42,140 /$. From the available literature, it is difficult to gain a consensual view on the influence of corticosteroids upon neurotrophin and neurotrophin receptor expression, probably because many neurotrophin responses occur only transiently and, thus, may be missed or misinterpreted in the majority of chronic studies (see Kuroda and McEwen /102/). Due to space constraints, the reader is referred to a recent comprehensive study of this subject by Hansson et al. $/ 67 /$. However, it is of interest to note here that high corticosteroid levels have been described to attenuate BDNF and NGF synthesis in the brain $/ 152,190,199,217 /$. Given that variations in the corticosteroid milieu compromise the fine structure of hippocampal neurons (see Section 6), a causal relationship between corticosteroids and neurotrophins and the maintenance of the structural integrity of the hippocampus seems likely. Interestingly, Trk receptors are apparently not influenced by either elevated (stress-induced) or diminished (ADX) levels of corticosteroids /30,199/, although low (MR activating?) doses of corticosterone reportedly upregulate $\operatorname{trkB} \mathrm{mRNA}$ transcripts in all hippocampal subfields /190/. The potential importance of the latter observations may be considerable in light of the emerging view that MR mediate neuroprotective effects, at least in the dentate gyrus (see Section 5).

Another neurotrophic factor, basic fibroblast growth factor (bFGF), which has been shown to play a prominent role in the differentiation of newly-born hippocampal cells /101/, also responds to variations in the corticosteroid environment $/ 30,67,176 /$. In light of the influence of corticosteroids on neuronal birth and survival, it is useful to consider a recent report that acute treatment with either MR or GR ligands results in significant increases in $b F G F$ mRNA levels throughout the hippocampus, whereas ADX produces the opposite effect $/ 67 /$. As discussed below, ADX results in increased cell proliferation as well as concomitant apoptosis in the dentate gyrus. Given that bFGF is a potent neurodifferentiation tactor, it will be interesting to better define the role of corticosteroid-associated changes in bFGF availability on the fate of newly-born dentate cells. From the bFGF results just described, one might predict that few of the cells generated in response to ADX would differentiate into fully-differentiated neurons, although several studies have shown the expression of neuronal markers in such cells. On the other hand, since changes in receptor availability may play a more prominent functional role than ligands. 
it is interesting to note that Hansson et al. /67/ observed $\mathrm{ADX}$ to acutely induce expression of the bFGF receptors 1 and 3 (bFGF-R1 and bFGF-R3), effects reversed by specific activation of MR and GR (cf. the lack of effects after chronic corticosteroid manipulations reported by Chao and McEwen $/ 30 /$ ). Interestingly, that study $/ 67 /$ also found the expression of FGF-R2 (mainly restricted to glial populations) to be upregulated in several hippocampal subfields (including the dentate gyrus) after MR activation, suggesting a role for MR in the differentiation and survival of dentate neurons. The latter may also be subject to influences by insulin growth factor-I (IGF-I) /33, 148,158,215/, and, indeed, GR activation by DEX has been shown to result in a reduction in the hippocampal levels of this growth factor $/ 1 /$.

To conclude this section, it needs to be emphasized that the above-cited target molecules may represent only a fraction of the plethora of molecules and pathways that may be involved in mediating corticosteroid actions on hippocampal neurogenesis and survival. To date, it is not yet clearly established whether any of these molecules are direct targets of corticosteroid receptor activation, or which of these mechanisms may operate in any given subpopulation of proliferating, differentiating or dying neurons.

\section{CRITICAL ANALYSIS OF OBSERVATIONS}

ASCRIBING HIPPOCAMPAL CELL DEATH TO ALTERATIONS IN THE CORTICOSTEROID MILIEU

As outlined in the introductory paragraphs of this review, the origins of the present interest in the effects of corticosteroids on the CNS, and in particular on the hippocampal formation, derive from the correlation between aging, hippocampal degeneration and hypercorticalism. The observations of Landfield et al. /103,105/ qualify as 'landmark studies' insofar as they demonstrated that endogenous corticosteroids, whose secretion is governed by natural programs, lead to hippocampal degeneration. Specifically, Landfield's work pioneered the idea that loss of hippocampal neurons may be directly linked to age-related increases in adrenocortical function $/ 103,105 /$. Thus, the aging program was considered to include, or at least serve as a risk factor for, hippocampal degeneration, an attractive view considering the well-documented association between increased age, cognitive decline and increased incidence of mood disorders $/ 11,76,117,118,130,135,235 /$. While the majority of published studies support Landfield's findings that adrenocortical secretions increase with age $/ 81$, 181 , a number of reports show that aged laboratory animals rather show decreased basal corticosteroid levels $/ 70 \%$. Nevertheless, there appears to be general agreement that aged humans and experimental animals show an exaggerated and prolonged adrenocortical response to stressful stimuli $/ 49,81$, 146/. The temporally extended responses of aged subjects appear to be causally related to impaired negative feedback in the hippocampal and hypothalamic circuits governing pituitary-adrenal activity, as evidenced by clinical tests, such as the dexamethasone suppression test (DST) /58,153/, and measurements of MR and GR in laboratory animals $/ 49,185 /$. The vicious circle triggered by aging, in which age-related hippocampal cell loss leads to a reduction in the number of corticosteroid feedback-mediating hippocampal cells and thus a further increase in adrenocortical secretion which, in turn, causes further neuronal death, was elegantly discussed in the review by Sapolsky et al. /187/. This review provided the impetus for our own explorations in this field, although, as will be seen, our and others' (including the proponents /104,129, 183/) interpretations sometimes differ slightly from the original formulation of the 'glucocorticoid cascade hypothesis of aging', at least with respect to hippocampal cell death.

The first study suggesting that elevated corticosteroid levels can result in hippocampal cell death /186/ was followed by a flurry of studies which supported this view $/ 35,108,144,221 /$. Most significant among these were observations indicating that chronic stress also induced hippocampal cell loss in the (castrated) rat $/ 144 /$ as well as in non-human primates $/ 221 \%$. In all of those studies, stress- or corticosterone-induced neuronal death, as measured by the presence of pyknotic cells in cresyl violetstained histological sections, was noted to occur only in the CA3 pyramidal subfield, although no plausible explanation has been given for this subfield-selective effect of stress. In this context, it 
is worth noting that even though the CA3 displays significant concentrations of GR, other hippocampal subfields (e.g. dentate gyrus and CA1) express similar (or even higher) GR mRNA and/or corticosteroid binding sites $/ 147,174,222 /$; this comment also applies to other studies showing that glucocorticoid effects on hippocampal survival occur mainly in the dentate gyrus (see below). The underlying mechanisms aside, it is worth noting that subsequent studies challenged the view that corticosteroid-induced cognitive impairments result from hippocampal cell loss /14,22/.

More recently, stereological methods have been applied to resolve the contentious issue of whether elevated glucocorticoid concentrations can indeed induce neuronal cell loss in the adult rodent and primate hippocampal formation. In fact, neither exogenous corticosterone/cortisol /107,201,205/ nor stress $/ 201,227 /$ was found to cause a significant loss of hippocampal neurons (Fig. 1), although DEX /204/ treatment led to a reduction in total residual cell numbers in specific hippocampal fields (dentate granule cells $>$ CA3 pyramidal cells) (Fig. 2A). The results from studies employing a different approach (quantification of apoptotic cells by TUNEL [terminal transferase-mediated dUTPbiotin nick end labeling]-histochemistry or silver/ methenamine staining) are consistent with these findings $/ 4,70,72 /$. Moreover, these observations support the view that corticosteroid effects on hippocampal cell survival occur in a ligand/ receptor-specific as well as hippocampal subfieldspecific fashion.

The present authors employed the synthetic GR agonist DEX in a series of studies in an attempt to analyze the specific role of GR in hippocampal cell death $/ 4,70,204 /$. The rationale behind the use of DEX was to circumvent the equivocal results produced in experiments using high doses of the endogenous ligand corticosterone which, as described earlier, binds to both MR and GR. Acute administration of DEX was found to cause significant apoptosis within the dentate granule and hilar subfields, the effect being several-fold stronger in aged as compared to young rats $/ 70 /$. GR activation did not induce apoptosis in any other hippocampal sub-area, an observation confirmed in a subsequent study in which rats were treated with
DEX for 10 days $/ 4 /$.

In contrast to GR, there is growing support for the view that MR play a neuroprotective role. A clear indication for this came from a study by Woolley et al. $/ 237 /$, who showed blockade of ADX-induced granule cell death by intravenous injections of the prototypic MR agonist aldosterone (as mentioned above, treatment with a pure GR agonist fails to interrupt the effects of ADX). These findings indeed confirm those reported earlier by Sloviter et al. /197,198/ that animals which are only partially ADX, i.e. still have low circulating levels of corticosterone which may be sufficient to occupy MR, fail to display apoptotic cell death in the dentate gyrus. Experiments from the authors' laboratories have also contributed to the hypothesis that MR occupation favors granule cell survival. Thus, these studies have shown that selective MR activation (low doses of corticosterone or aldosterone) does not induce apoptosis $/ 4,70 /$ in the rat dentate gyrus. On the other hand, the cell deathinducing effects of GR activation by DEX were significantly attenuated by the co-administration of either aldosterone $/ 204 /$ (Fig. 2B) or low, MRactivating doses of corticosterone $/ 4,70 /$. Interestingly, the neuronal rescue observed in the latter studies occurred in both young and aged rats, an important point when considered in light of the greater vulnerability of older subjects to DEXinduced apoptosis.

In summary, there is now good evidence that whereas activation of GR leads to hippocampal cell death (most probably apoptotic), activation of MR triggers neuroprotective mechanisms; the latter may be sufficiently powerful to overcome the death associated with GR activation. Together, these observations add weight to de Kloet's 'pendulum hypothesis' /40/ of corticosteroid actions in the hippocampus. Since corticosteroid receptors are primarily transcriptional factors, it is most likely that the above-mentioned MR- and GR-mediated actions result from the activation or repression of specific genes or whole genetic programs; surprisingly, however, there is a notable paucity of information on this issue in the context of hippocampal survival in intact animals. Having obtained evidence that GR activation leads to increased apoptosis among the granule cell 


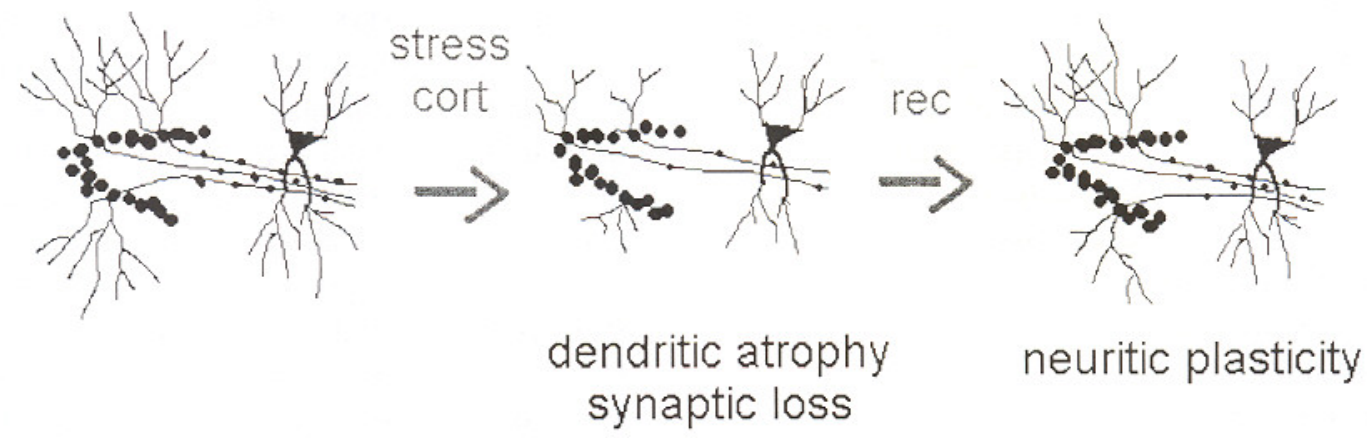

Fig. 1: Schematic representation of the effects of stress or corticosterone treatment, and recovery from these experimental conditions, upon hippocampal structure. Exposure to stress or corticosterone (cort) does not induce hippocampal cell loss but leads to dendritic atrophy in granule and pyramidal cells; these treatments also cause a decrease in the number of MFCA3 synapses. Normal dendritic morphology and number of MF-CA3 synaptic contacts are observed after a period of recovery (rec) from these experimental conditions.

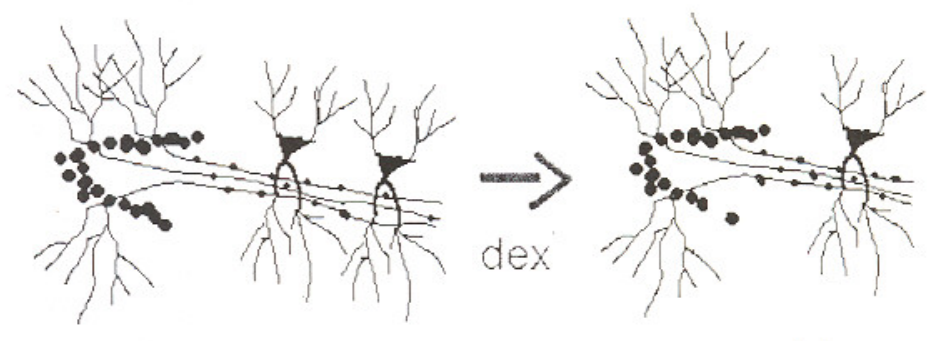

\section{neuronal loss}

\section{A}
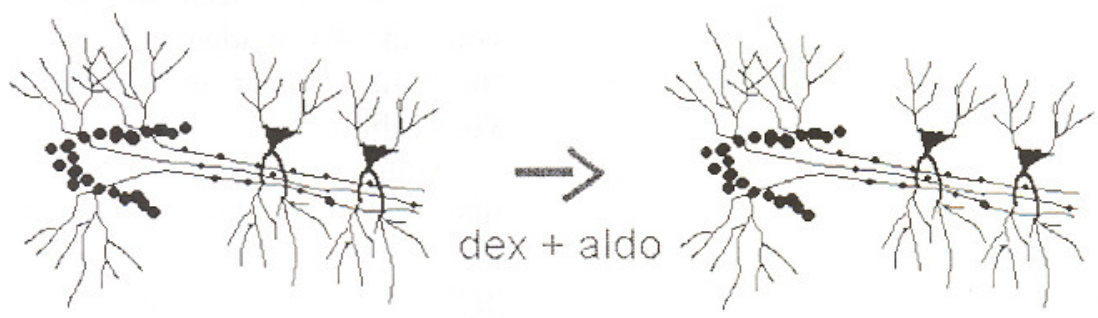

B

Fig. 2: Schematic representation of the effects of (A) the glucocorticoid receptor agonist dexamethasone (dex) and (B) dex plus the mineralocorticoid receptor agonist aldosterone (aldo) treatment upon hippocampal structure. The loss of neurons in the granule and CA3 pyramidal fields induced by dexamethasone alone are attenuated by aldosterone. 
population of the rat, we recently examined whether these changes were accompanied by alterations in the expression of key pro- and antiapoptotic molecules /4/. That study strongly indicated that the opposing actions of MR and GR on neuronal survival result from their ability to differentially influence the expression of the antiapoptotic proteins $\mathrm{Bcl}-2$ and $\mathrm{Bcl}-\mathrm{x}_{\mathrm{L}}$ relative to that of the pro-apoptotic protein Bax. Thus, in both young and old rats, activation of GR with DEX was associated an increase in the ratio of Bax relative to molecules Bcl-2 or Bcl- $\mathrm{x}_{\mathrm{L}}$ and apoptosis, whereas the opposite effects were observed after stimulation of MR with low doses of corticosterone; furthermore, the expression ratios of these molecules after co-administration of low, MR-activating doses of corticosterone and DEX were compatible with the earlier-described ability of MR activation to subjugate the pro-apoptotic actions of GR stimulation. In the same study, we unequivocally demonstrated the essential contribution of Bax to the GRactivated cell death-signaling cascade, as DEX proved ineffective in stimulating apoptosis in bax knockout mice.

To date, there is no evidence available for direct corticosteroid receptor (MR or GR) regulation of $b c l-2, b c l-x_{L}$ or bax; moreover, none of these genes contain cognate hormone (corticosteroid) response elements in their promoter regions. On the premise that the tumor suppressor protein p53 (also a transcriptional factor) was previously demonstrated to be a direct transcriptional enhancer of bax and repressor of $b c l-2 / 142,143 /$, we were interested to know whether occupation of GR and MR differentially influenced hippocampal p53 protein levels. Indeed, we found that p53 expression was oppositely influenced by GR (increased) and MR (decreased) activation $/ 4 /$, thus providing further clues about the early genetic events underlying MR- and GR-mediated hippocampal cell survival and death.

A role for p53 in ADX-induced apoptosis within the granule cell sub-population of the hippocampus has also been suggested. Indeed, Schreiber et al. /191/ showed that ADX leads to increased hippocampal expression of the mRNA encoding p 53, and later demonstrated that mice with a null mutation of the $p 53$ gene show reduced granule cell apoptosis in response to $\mathrm{ADX} / 178 /$. Studies (in the rat) from one of the authors' laboratories have shown that ADX-induced changes in p53 expression may ultimately be manifest as increased bax:bcl-2 mRNA ratios which, as in the case of GR stimulation, are associated with granule cell death (Condé et al., unpublished observations). Adding support to the view that members of the Bcl-2 family are critically involved in granule cell death following alterations in the corticosteroid milieu is the fact that, in the latter studies by Condé et al., the alterations in the ratios of bax:bcl-2 were less pronounced in aged rats (which show less severe ADX-induced apoptosis) than in young animals.

Age-related vulnerability may also be a consequence of alterations in the expression of MR and GR. Significant declines in the levels of both receptors have been described to occur during aging, the slope of decline being greater for MR than GR /69,223/. These changes in receptor density may at least partly account for the greater vulnerability of aged subjects to the apoptotic effects following GR occupation /4/. In contrast, the lesser susceptibility of aged rats to ADXinduced apoptosis might result from a more robust expression of anti-apoptotic genes (Condé et al., unpublished observations). Whilst all or most of the necessary neuroprotective mechanisms appear to be intact in aged subjects, older animals may lack the appropriate 'triggers' to exploit these mechanisms. On the basis of our previous studies in which low corticosterone therapy aimed to occupy MR proved more effective at protecting aged animals against the apoptosis-inducing effects of GR occupation, as well as observations that basal corticosterone secretion is reduced in aged animals, one may conclude that inadequate activation of MR may be the causal factor in increased hippocampal cell vulnerability.

Although the preceding paragraphs may suggest that the molecular cascades underlying corticosteroid effects on hippocampal cell survival and death are now defined, some cautionary remarks are merited and numerous questions remain open. For example, the nature of GR-p53 interactions still needs to be clarified. In vitro studies have raised a number of possibilities, including physical interactions between GR and p53 /240/, GR-mediated 
stabilization of p53/122,194/, and enhancement of the transactivational potential of p53 by GR (Crochemore et al., unpublished observations). Furthermore, how does one explain the opposite consequences of MR vs GR occupation on granule cell survival? Can these receptors, hitherto known to bind to an identical hormone response element (HRE), direct gene transcription or repression via other, as yet unknown, DNA binding sites, or does each receptor recruit different co-activator/ -repressor partners? What is the functional importance of $\mathrm{MR} / \mathrm{GR}$ heterodimer formation in terms of cell death/survival gene expression? Lastly, how do both the absence of corticosteroids (ADX) and activation of GR lead to the same morphological endpoint in the granule cell layer, i.e. apoptosis, albeit to differing extents? While some of the answers to the differential activation of hippocampal genes by ADX and GR and MR activation may be expected from the application of differential gene display and DNA array assays (see $/ 39,228 /$ ), the involvement of non-genomic events should also be considered /123/. This may be especially interesting because some of the metabolic changes induced by glucocorticoids (e.g. increased ROS production, decreased glucose uptake and reduced protein synthesis) closely resemble or parallel some of the changes observed after decreases in MAP kinase and phosphatidylinositol 3-kinase (PI3-kinase) activities, which have been closely linked to the promotion of cell survival by growth factors; the downstream target of PI3-kinase is a proto-oncogene serine/threonine kinase termed protein kinase B (PKB)/Akt which, by decreasing calpain levels, suppresses caspase activation and subsequent apoptosis $/ 53,88,93 /$.

Finally, it should be emphasized that, whereas many authors, including ourselves, have worked on the premise that corticosteroids may themselves produce neurotoxic effects, Sapolsky's work has led to the development of a convincing alternative view. Accordingly, corticosteroids may not be neurotoxic per se, but rather, may render neurons (more) vulnerable to the insults imposed by other agents, such as excitatory amino acids /166,182, $210 /$, ischemia $/ 97,188 /$, hypoglycemia and antimetabolite toxins $/ 212 /$, cholinergic and serotonergic toxins $/ 6,79,86 /, \beta$-amyloid fragment $/ 18$,
59/, gp-120 glycoprotein of HIV /26,242/ and ROS $/ 138,139 /$. The last may be particularly important in the context of brain aging when neurons apparently become increasingly exposed and probably more sensitive to free radicals $/ 9,38,68 /$; increases in ROS are consequences of many diseases showing clear increases in incidence with increased age (e.g. hypertension, diabetes mellitus, dislipidemia).

\section{CORTICOSTEROIDS AND FINE STRUCTURAL CHANGES IN THE HIPPOCAMPAL FORMATION}

From the previous section, it seems unlikely that the relatively minor loss of hippocampal cells found following exposure to stress or high corticosteroid levels makes a significant contribution to the decline in cognitive abilities that occurs in association with these conditions. Accordingly, a more recent approach has been to look for other structural correlates of the cognitive deficits observed after chronic hypercorticalism and stress. Changes in neuritic structure were the focus of the these latter studies.

Early studies showed that hypercorticalism (pharmacological or stress-induced) induces atrophy of CA3 pyramidal cell dendrites $/ 54,120,229,230$, $236 /$, and more recent work has reported similar effects in all major subdivisions of the hippocampal formation /202/. These newer studies also reported marked synaptic loss in at least one of the links of the intrinsic hippocampal circuitry (the mossyfiber-CA3 connection) $/ 202 /$. One may therefore conclude that elevated corticosteroids trigger structural responses within cytoplasmic organelles. dendrites, axons and their synaptic contacts /121,141,202/; importantly, such changes do not necessarily involve the irreversible loss of neurons /201/. Since this interpretation may seem to contradict the previously-described induction of cell death by high corticosteroids, it is important to note that elevation of circulating corticosteroids by either stress or exogenous corticosteroids may cause sufficient, albeit transient, stimulation of cytoprotective MR. This interpretation is consistent with published studies $/ 4,70,204 /$ in which it was shown that activation of MR prior to exposure to a GR-specific drug (DEX) can attenuate the apoptosis-inducing effects of the GR agonist. In the 
case in which dendritic, axonal and/or synaptic losses occur but neuronal soma are spared, it would seem that the balance between MR vs GR occupation is only partially disturbed, thus permitting eventual recovery. Such reasoning might explain how an organism can minimize the impact of certain insults, allowing itself to re-achieve a new equilibrium through adaptation - i.e. it recovers allostasis, as McEwen would put it /130/.

Neuritic alterations of the type described above correlate with behavioral deficits and would appear to serve as the neuroanatomical basis of adaptive mechanisms underlying learning and memory /149,177/. Cellular mechanisms of learning and memory have long been believed to include alterations in dendrites (mainly in spines) and in the number and structure of synapses /167/. The validity of this notion has been explored in a number of quantitative light and electron microscopical studies that, in the majority of cases, showed that the numerical density of synapses was increased as a consequence of learning of novel behaviors. For example, using the brightness discrimination model, an increased density of synapses was observed in the stratum radiatum of CA1/233/, and increased spine density was seen in the molecular layer of the dentate gyrus of animals exposed to the passive avoidance conditioning paradigm $/ 225 /$. In the latter setting, the numerical density of dendritic spines per unit volume in the molecular layer of the rat dentate gyrus was also increased $/ 160 /$. More recent studies have also shown that, despite numerical changes in dendritic spines and synapses, cellular mechanisms of hippocampus-dependent associative learning include the remodeling of existing hippocampal synapses; thus, increases in the area of the postsynaptic density after conditioning were found in axospinous nonperforated synapses; these changes most likely reflect an involvement of signal transduction proteins and the transformation of silent postsynaptic synapses into active ones /57/. In light of these robust correlations between neuritic (dendritic spine and synapse) changes and cognitive performance, it seems warranted to conclude that perturbations of these cellular parameters will result in a diminution of performance in hippocampus-dependent learning tasks.
McEwen recently suggested a provocative, but fascinating, idea: neuronal atrophy observed following sustained hypercorticalism might represent a plastic event that may in fact ensure neuronal protection $/ 132 /$. He proposed that neuritic atrophy might serve to attenuate the excitotoxic cascade triggered by hypercorticalism, thus hampering the progression of cellular events that would ultimately lead to the demise of the neuron. Obviously, these adaptations would trigger some functional impairment as a result of the accompanying neuritic atrophy and synaptic loss, i.e. here, in contrast to our usual view, plasticity would have negative consequences, but the adaptive advantages of this price would outweigh the cost of irreversible (or hard-to-replace) neuronal loss. An implicit part of this concept is that preservation of the cell body provides for reorganization (re-growth of dendrites and axons and establishment of new synapses) of damaged neuronal circuits after a period of recovery from the insult.

There is growing evidence for the validity of the above proposition. For example, studies in rats have shown that, whereas no significant structural re-organization occurs during or immediately after the termination of elevated corticosteroid levels (by pharmacological means or after the imposition of stressors), significant re-organization does occur within 1 month of withdrawal from the damaging stimulus $/ 202 /$. This so-called 'reactive synaptogenesis' occurs throughout the hippocampal formation and is commensurate with restorations of spatial learning and memory to levels found in control animals /202/ (Fig. 1). Together, the recent findings match well with older observations that hypercorticalism-induced cognitive impairment is a reversible phenomenon $/ 116,135 /$.

Importantly, regeneration of dendritic, axonal and synaptic elements also seems to be possible after profound neuronal loss, as is observed in the dentate granule cell layer after adrenalectomy /203/. This manipulation is also accompanied by marked collapse of the mossy fiber inputs to the CA3 pyramidal layer. Administration of low doses of corticosterone to adrenalectomized rats can, at least partially, restore the total dendritic length of granule cells and the volume and surface area of the mossy fiber terminals. In addition, corticosterone- 
substitution therapy results in complete recovery of the volume of the suprapyramidal bundle, number and surface area of mossy fiber-CA3 synapses, and the surface area of dendritic excrescences /203/ (Fig. 3). These observations on the fine structural adjustments concur with the results of other work showing that behavioral functions impaired by adrenalectomy can be partially reinstated by the administration of corticosterone /36,128/.

The evidence summarized above firmly indicates that alterations of the corticosteroid milieu can induce profound, but largely reversible, changes in the ultrastructural organization of the hippocampal formation; these bi-directional alterations, more than changes in neuron viability, may represent the neuroanatomical correlate of hippocampusdependent learning and memory. Presently, there is no clear data available as to what neurochemical mechanisms might underlie the fine structural observations described above. However, NMDA and 5-HT receptors appear to be key candidates, since the administration of either NMDA antagonists or serotonin re-uptake inhibitors have been shown to abrogate CA3 dendritic atrophy /120, 229/. Growth factors also seem to be likely mediators in view of data showing that elevated corticosteroid levels (including those produced in response to stress) attenuate hippocampal BDNF and NGF levels and that adrenalectomy results in significant reductions in the levels of NT-3 $/ 13,199 /$. Interestingly, administration of NT-4/5 (but not NT-3) significantly attenuates the massive neuronal death which occurs in adrenalectomized animals /165/. Lastly, it seems highly plausible that neurotrophins play a major role in the neuritic regrowth seen after recovery from exposure to high corticosteroid levels, because the recovery phase is characterized by an augmentation of neurotrophin synthesis /199/.

\section{CORTICOSTEROIDS AND NEURONAL BIRTH IN THE DENTATE GYRUS}

It is now firmly established that structural correlates of neural plasticity include synaptic reorganization $/ 57,94,202 /$; the demonstration that new neurons can also be incorporated into circuits of known functional relevance has added an additional exciting dimension to the field $/ 5,15,51$, 61/. The dentate gyrus represents one of a limited number of brain areas in which neurogenesis occurs throughout life within the so-called 'subgranular' or 'germinative' zone of the dentate gyrus $/ 5,15,100 /$. It is important to note, however, that the rate of new cell acquisition is not constant, being higher during early stages of life and declining with increasing age $/ 100 /$. In parallel with the process of neuronal acquisition, neuronal death also occurs in this region of the brain /63-65/. However, it is relevant to mention that, at least during the prenatal period, the rate of neuronal death is approximately one order of magnitude lower than the rate of granule cell acquisition $/ 64,65 /$. The prolonged period of granule cell proliferation in the dentate gyrus makes it unusually susceptible to experience-dependent
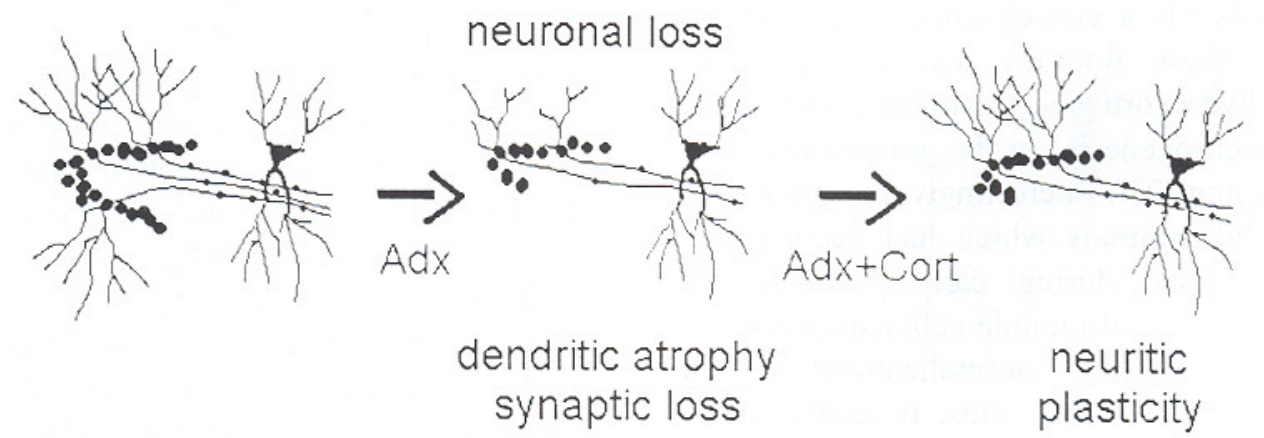

Fig. 3: Schematic representation of the morphologic effects of adrenalectomy and corticosterone replacement upon hippocampal structure. Removal of the adrenals ( $\mathrm{Adx}$ ) leads to granule cell loss but also to dendritic atrophy in surviving neurons and a reduction in the number of mossy fiber (MF)-CA3 synapses. Remarkable neuritic plasticity is manifested after corticosterone replacement therapy; this includes restoration of dendritic lengths and numbers of MF-CA3 synapses to values similar to those found in adrenal-intact subjects. 
structural changes $/ 48,61,62,196 /$. In support of this notion, a strong body of evidence demonstrates that the rate of acquisition, survival and death of new granule cells can be enhanced or diminished by several factors. Amongst positive regulators are estrogens, physical activity and enriched or complex environments $/ 51,61 /$. On the other hand, deprivation, excitatory inputs, adrenal steroids and stressful experiences are known to decrease the number of newly-generated dentate granule cells $/ 60,61 /$. Whereas the occurrence of cell birth in the dentate gyrus has been known for a considerable period of time, it is only in the last few years that evidence for corticosteroid regulation of this process has been provided. That evidence points to a negative influence of corticosteroids on neurogenesis, with several studies demonstrating that high levels of corticosteroids, both during the stress-hyporesponsive period during early postnatal life and in adulthood, decrease the number of new granule cells $/ 60,61,64 /$; conversely, the removal of the adrenals, even in the aged rat, restores high levels of cell proliferation in the dentate gyrus $/ 63,64 /$. Demonstrations showing that blockade of NMDA receptors can attenuate the inhibitory effects of stress on granule cell birth suggest that similar mechanisms may underlie the suppression of neurogenesis by stimulation of GR /60,61/. To date, the role of MR in the regulation of neurogenesis is not known.

It is now known that prolonged corticosterone treatment in early phases of life leads to a reduction in the total number of granule cells (probably due to decreased cell acquisition), but also CA3 pyramidal cells (as a consequence of deafferentiation) $1205 /$; these findings accord with earlier reports that hydrocortisone treatment shortens the 'window of neurogenesis' in the granule cell layer of the cerebellum /23/. Interestingly, morphological studies in adult animals which had been treated with corticosterone during early postnatal life indicate that the rate of granule cell acquisition can be restored following normalization of the corticosteroid milieu $/ 205 /$; thus, it seems justifiable to conclude that the proliferative potential of granule precursor cells is not irreversibly compromised by corticosteroids.
Although several studies have shown that dentate granule cells generated in adulthood do in fact receive synaptic inputs $/ 89 /$, extend axons into the mossy-fiber pathway $/ 71,100,206 /$, and express a number of markers of mature neurons $/ 28,125 /$, it is yet to be established whether these newlygenerated neurons simply replace "holes" left by old degenerating neurons or, alternatively, whether they constitute an additive supplement that not only maintains but also extends the potential of hippocampus-dependent functions. Other important and interesting questions still to be addressed with respect to corticosteroid influences on neurogenesis include: (i) How do corticosteroids affect granule progenitor cells in the subgranular zone vs stem cell populations in the subventricular zone that may also contribute to neurogenesis in the hippocampus? (ii) Do the reported effects of corticosteroids relate directly to cell proliferative events, or do they reflect actions on the survival of newlyborn cells? and (iii) How do corticosteroids affect other events associated with the generation of new granule neurons (e.g. the migration and differentiation of recently-produced cells)?

\section{CONCLUSIONS}

Rather than reiterating information accessible in the literature or expounding dogmas, this paper has striven to outline the historical development of interest in the role of corticosteroids in hippocampal structure and function, primarily because it was considered that such a perspective may provide a refreshed understanding of how some of the present-day thoughts on the subject have evolved. One of the other major goals of this work was to inspire further research, especially for newcomers to the field, by raising questions about some of the established concepts (and misconceptions). Thus, for example, a substantial amount of space is dedicated to a discussion of why the oft-made assumption that the stress response can be equated with increased adrenocortical activity is an erroneous one. Many of the early studies in this field were purely descriptive ones, later supplemented with correlations based on loss- and gainof-function models. Several of the ideas formulated on the basis of the earlier studies eventually failed 
to withstand detailed experimental analysis (e.g. that increased corticosteroid secretion and stress lead to hippocampal cell loss). Nevertheless, it cannot be emphasized sufficiently that it was such work that provided the framework for much of what we know about the subject today.

A number of interesting facts has emerged from some of the more recent studies. For example, the duality of corticosteroid receptors has been shown to be of considerable importance in determining hippocampal cell fate (GR as promoters of cell death; MR as mediators of cell survival), complementing other work showing that GR and MR are differentially involved in the acquisition, storage and retrieval of spatial information - cognitive processes for which the hippocampus is best known. These findings lend further support to the previously-advanced view that optimal occupation of MR and GR is pivotal to hippocampal structure and function. Other interesting newer findings include: (i) the demonstration that manipulations of the corticosteroid environment which lead to an imbalance in the activity of corticosteroid receptors induce cell losses in certain hippocampal subfields (dentate gyrus) that had not previously been shown to be sensitive to the degenerative effects of corticosteroids, with reduced MR activity, rather than GR occupation, being the primary cause of neuronal death; (ii) GR may play a crucial role in the structural plasticity of hippocampal neurons; and (iii) the recognition that re-organization of axodendritic and synaptic elements may represent the fine structural correlate of corticosteroid-associated plasticity, thus accounting for reversible changes in behavior (Fig. 4).

In the last few years, demonstrations that corticosteroids can influence hippocampal (granule) cell birth have added yet one more facet to the ways in which corticosteroids can contribute to the anatomy of the hippocampal formation. Together with the better-known effects of corticosteroids on neuronal degeneration and dendritic atrophy, these observations open many vistas for studying the mechanisms by which corticosteroids may play a part in determining the life history - genesis, differentiation and death - of at least subpopulations of hippocampal neurons. Obviously, the functional significance as well as the clinical relevance and therapeutic potential of many of the newer discoveries still remain to be established.

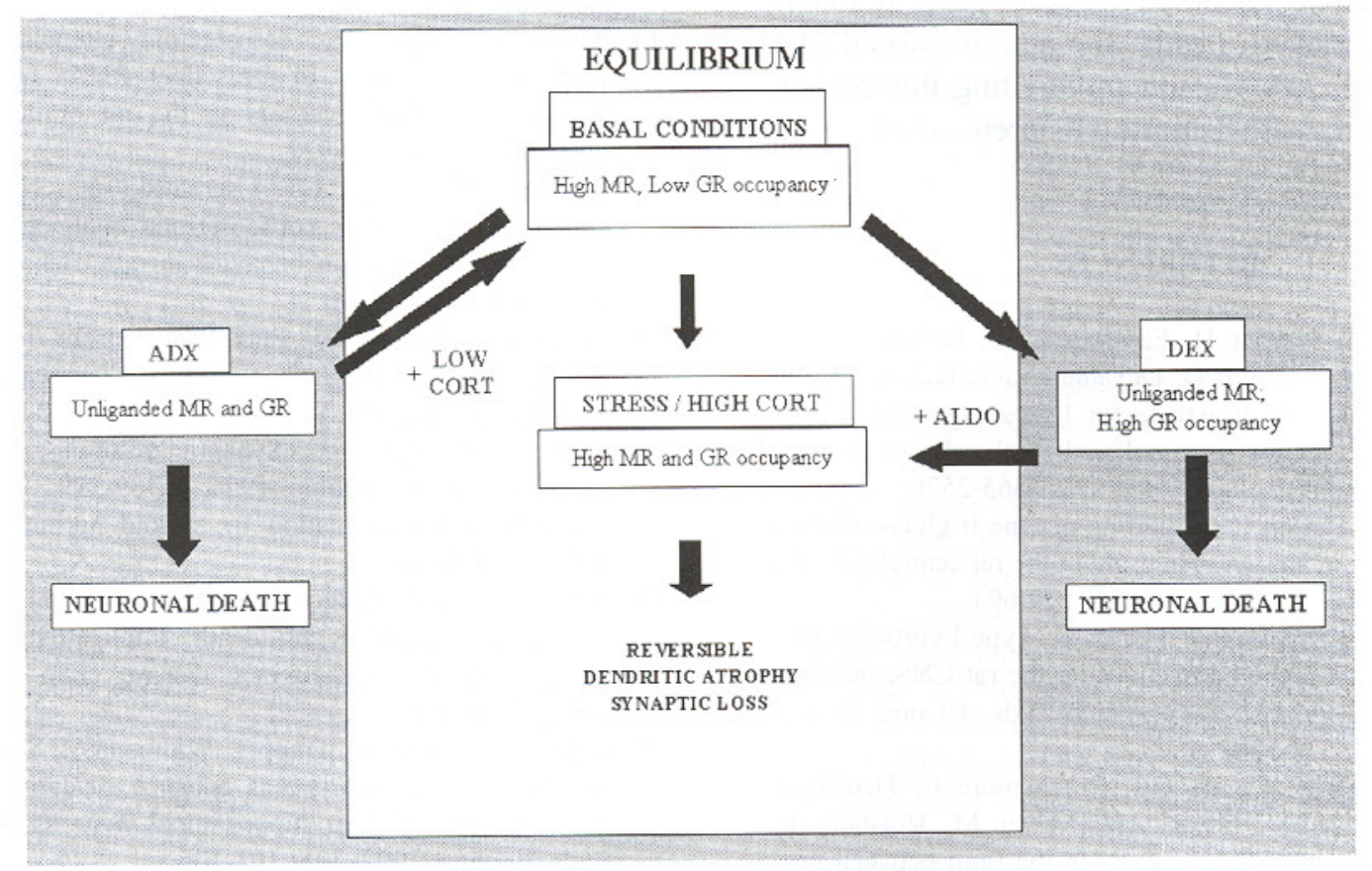

Fig. 4: Proposed revised version of the "pendulum hypothesis" of corticosteroid actions in the brain, with special reference to the corticosteroid effects on hippocampal morphology. 
Answers to these questions are most likely to come by exploiting a combination of all the currently available physiological (including during aging, stress and recovery from stress), pharmacological and surgical (adrenalectomy) models for examining the role of corticosteroids, since each of these has brought us significant amounts of information in the past.

\section{ACKNOWLEDGEMENTS}

The authors are grateful to members of their laboratories who contributed to the studies reviewed here. In particular, they would like to thank Professors Manuel Paula-Barbosa and Florian Holsboer for their encouragement, and the Institute of Anatomy of Porto Medical School, the Max Planck Society and Acções Integradas LusoAlemãs for supporting the authors' joint studies. The authors have attempted to provide an overview of a subject to which numerous scientists have contributed; it is hoped that their efforts to present an integrated picture in an unbiased manner has not resulted in an over-simplification, and they apologize to any author whose work has either not been given sufficient coverage or has been unintentionally overlooked. Lastly, the authors would like to thank Prof. J.P. Huston for inviting this review and for bearing with us during its preparation.

\section{REFERENCES}

I. Adamo M, Werner H, Farnsworth W, Roberts CT Jr, Raizada M, LeRoith D. Dexamethasone reduces steady state insulin-like growth factor I messenger ribonucleic acid levels in rat neuronal and glial cells in primary culture. Endocrinology 1988; 123: 2565-2570.

2. Ahima R, Harlan RE. Charting of type II glucocorticoid receptor-like immunoreactivity in the rat central nervous system. Neuroscience 1990; 39: 579-604.

3. Ahima R, Krozowski Z, Harlan R. Type I corticosteroid receptor-like immunoreactivity in the rat CNS: distribution and regulation by corticosteroids. J Comp Neurol 1991: 313: 522-538.

4. Almeida OFX, Conde GL, Crochemore C, Demeneix $B \wedge$, Fischer D, Hassan $A H$, Meyer $M$, Holsboer $F$, Michaelidis TM. Subtle shifts in the ratio between proand antiapoptotic molecules after activation of corticosteroid receptors decide neuronal fate. FASEB J 2000; 14: $779-790$.
5. Altman J, Bayer SA. Migration and distribution of two populations of hippocampal granule cell precursors during the perinatal and postnatal periods. J Comp Neurol 1990; 301: 365-381.

6. Amoroso D, Kindel G, Wulfert E, Hanin I. Long-term exposure to high levels of corticosterone aggravates AF64A-induced cholinergic hypofunction in rat hippocampus in vivo. Brain Res 1994; 661: 9-18.

7. Applezweig N. Steroid drugs. New York: McGraw-Hill, $1962 ; 17-20$.

8. Arriza JL, Weinberger C, Cerelli G, Glaser TM, Handelin BL, Housman DE, Evans RM. Cloning of human mineralocorticoid receptor complementary DNA: structural and functional kinship with the glucocorticoid receptor. Science 1987; 237: 268-275.

9. Ashok BT, Ali R. The aging paradox: free radical theory of aging. Exp Gerontol 1999; 34: 293-303.

10. Aus der Muhlen K, Ockenfels H. Morphologishe Veränderungen im Diencephalon und Telencephalon nach Storngen des Regelkreises Adenohypophyse-Nebennierenrinde III. Ergebnisse beim Meerschweinchen nach Verabreichung von Cortison und Hydrocortison. Z Zellforsch 1969; 93: 126-141.

11. Axelson DA, Doraiswamy PM, McDonald WM, Boyko OB, Tupler LA, Patterson LJ, Nemeroff CB, Ellinwood EH Jr, Krishnan KR. Hypercortisolemia and hippocampal changes in depression. Psychiatry Res 1993; 47: 163-173.

12. Baeuerle PA, Baichwal VR. NF-kappa B as a frequent target for immunosuppressive and anti-inflammatory molecules. Adv Immunol 1997; 65: 111-137.

13. Barbany G, Persson H. Adrenalectomy attenuates kainic acid-elicited increases of messenger RNAs for neurotrophins and their receptors in the rat brain. Neuroscience 1993; 54: 909-922.

14. Bardgett ME, Taylor GT, Csernansky JG, Newcomer JW, Nock B. Chronic corticosterone treatment impairs spontaneous alternation behavior in rats. Behav Neural Biol 1994; 61: 186-190.

15. Bayer SA, Yackel JW, Puri PS. Neurons in the rat dentate gyrus granular layer substantially increase during juvenile and adult life. Science 1982; $216: 890-892$.

16. Bear MF, Malenka RC. Synaptic plasticity: LTP and LTD. Curr Opin Neurobiol 1994; 4: 389-399.

17. Beato M. Gene regulation by steroid hormones. Cell 1989; 56: 335-344.

18. Behl C. Effects of glucocorticoids on oxidative stressinduced hippocampal cell death: implications for the pathogenesis of Alzheimer's disease. Exp Gerontol 1998; 33: 689-696.

19. Behl C, Lezoualc'h F, Trapp T, Widmann M, Skutella T, Holsboer F. Glucocorticoids enhance oxidative stressinduced cell death in hippocampal neurons in vitro. Endocrinology 1997; 138: 101-106.

20. Bennett MR. The concept of long term potentiation of transmission at synapses. Prog Neurobiol 2000; 60: 109 137. 
21. Bliss TV, Collingridge GL. A synaptic model of memory: long-term potentiation in the hippocampus. Nature 1993; 361:31-39.

22. Bodnoff SR, Humphreys AG, Lehman JC, Diamond DM, Rose GM, Meaney MJ. Enduring effects of chronic corticosterone treatment on spatial learning, synaptic plasticity, and hippocampal neuropathology in young and mid-aged rats. J Neurosci 1995; 15:61-69.

23. Bohn MC, Lauder JM. Cerebellar granule cell genesis in the hydrocortisone-treated rats. Dev Neurosci 1980; 3 : 81-89.

24. Bremner JD, Narayan M, Anderson ER, Staib LH, Miller HL, Charney DS. Hippocampal volume reduction in major depression. Am J Psychiatry 2000; 157: 115118.

25. Bremner JD, Randall P, Scott TM, Bronen RA, Seibyl JP, Southwick SM, Delaney RC, McCarthy G, Charney DS, Innis RB. MRI-based measurement of hippocampal volume in patients with combat-related posttraumatic stress disorder. Am J Psychiatry 1995; 152: 973-981.

26. Brooke SM, Howard SA, Sapolsky RM. Energy dependency of glucocorticoid exacerbation of gp120 neurotoxicity. J Neurochem 1998; 71: 1187-1193.

27. Buchman AL. Side effects of corticosteroid therapy. J Clin Gastroenterol 200 1; 33: 289-294.

28. Cameron HA, Woolley CS, Gould E. Adrenal steroid receptor immunoreactivity in cells born in the adult rat dentate gyrus. Brain Res 1993; 611: 342-346.

29. Canteros G, Conde GL, von Rosenstiel P, Almeida OFX. Nitric oxide mediates dexamethasone-induced apoptosis in the dentate gyrus: the protective actions of D-arginine. Soc Neurosci Abst 1998; Abst. 418.14.

30. Chao HM, McEwen BS. Glucocorticoids and the expression of mRNAs for neurotrophins, their receptors and GAP-43 in the rat hippocampus. Mol Brain Res 1994; 26: 271-276.

31. Chao MV, Hempstead BL. p75 and Trk: a two-receptor system. Trends Neurosci 1995; 18: 321-326.

32. Chen Sy, Wang J, Yu Gq, Liu W, Pearce D. Androgen and glucocorticoid receptor heterodimer formation. A possible mechanism for mutual inhibition of transcriptional activity. J Biol Chem 1997; 272: 1408714092

33. Cheng CM, Cohen M, Tseng V, Bondy CA. Endogenous IGF1 enhances cell survival in the postnatal dentate gyrus. J Neurosci Res 2001; 64: 341-347.

34. Cintra A, Zoli M, Rosen L, Agnati LF, Okret S, Wikstrom AC, Gustaffsson JA, Fuxe K. Mapping and computer assisted morphometry and microdensitometry of glucocorticoid receptor immunoreactive neurons and glial cells in the rat central nervous system. Neuroscience 1994; 62: 843-897.

35. Clark AS, Mitre MC, Brinck-Johnsen T. Anabolicandrogenic steroid and adrenal steroid effects on hippocampal plasticity. Brain Res 1995; 679: 64-71.

36. Conrad C, Roy E. Dentate gyrus destruction and spatial memory impairment after corticosteroid removal in young and middle-aged rats. Hippocampus 1995; 5: 1-15.

37. Coussens CM, Kerr DS, Abraham WC. Glucocorticoid receptor activation lowers the threshold for NMDAreceptor-dependent homosynaptic long-term depression in the hippocampus through activation of voltagedependent calcium channels. J Neurophysiol 1997; 78: $1-9$.

38. Coyle J, Puttfarken P. Oxidative stress, glutamate and neurodegenerative disorders. Science 1993; 262: 684690.

39. Datson NA, van der Perk J, de Kloet ER, Vreugdenhil E. Identification of corticosteroid-responsive genes in rat hippocampus using serial analysis of gene expression. Eur J Neurosci 2001; 14: 675-689.

40. de Kloet ER. Brain corticosteroid receptors balance and homeostatic control. Front Neuroendocrinol 1991; 12: 95-164.

41. de Kloet ER, Oitzl MS, Joels M. Stress and cognition: Are corticosteroids good or bad guys? Trends Neurosci 1999; 22: 422-426.

42. Dechant G. Molecular interactions between neurotrophin receptors. Cell Tissue Res 2001; 305: 229-238.

43. Diamond DM, Bennett MC, Fleshner M, Rose GM Inverted- $U$ relationship between the level of peripheral corticosterone and the magnitude of hippocampal primed burst potentiation. Hippocampus 1992; 2: 421-430.

44. Doi N, Miyahara S, Hori N. Glucocorticoids promote localized activity of rat hippocampal CAI pyramidal neurons in brain slices. Neurosci Lett 1991; 123:99-101.

45. Doyle P, Guillaume-Gentil C, Rohner-Jeanrenaud F, Jeanrenaud B. Effects of corticosterone administration on local cerebral glucose utilization of rats. Brain Res 1994; 645: 225-230.

46. Du AT, Schuff N, Amend D, Laakso MP, Hsu YY, Jagust WJ, Yaffe K, Kramer JH, Reed B, Norman D, Chui HC, Weiner MW. Magnetic resonance imaging of the entorhinal cortex and hippocampus in mild cognitive impairment and Alzheimer's disease. J Neurol Neurosurg Psychiatry 2001; 71: 441-447.

47. Dugan LL, Choi DW Excitotoxicity, free radicals, and cell membrane changes. Ann Neurol 1994; 35: S17-21.

48. Duman RS, Malberg J, Nakagawa S. Regulation of adult neurogenesis by psychotropic drugs and stress. J Pharmacol Exp Ther 2001; 299: 401-407.

49. Eldridge JC, Brodish A, Kute TE, Landfield PW. Apparent age-related resistance of type II hippocampal corticosteroid receptors to down-regulation during chronic escape training. J Neurosci 1989; 9: 3237-3242.

50. Endo Y, Nishimura J, Kimura F. Adrenalectomy increases local cerebral blood flow in the rat hippocampus. Pflügers Arch 1994; 426: 183-188.

51. Eriksson PS, Perfilieva E, Bjork-Eriksson T, Alborn AM, Nordborg C, Peterson DA, Gage FH. Neurogenesis in the adult human hippocampus Nature Med 1998; 4: 1313-1317.

52. Evans RM The steroid and thyroid hormone receptor superfamily. Science 1988; 240: 889-895. 
53. Eves EM, Xiong W, Bellacosa A, Kennedy SG, Tsichlis PN, Rosner MR, Hay N. Akt, a target of phosphatidylinositol 3-kinase, inhibits apoptosis in a differentiating neuronal cell line. Mol Cell Biol 1998; 18: 2143-2152.

54. Fuchs E, Uno H, Flugge G. Chronic psychosocial stress induces morphological alterations in hippocampal pyramidal neurons of the tree shrew. Brain Res 1995; 673:275-282.

55. Funder JW. Mineralocorticoid receptors in the central nervous system. J Steroid Biochem Mol Biol 1996; 56: 179-183.

56. Fuxe K, Harfstrand A, Agnati LF, Yu ZY, Cintra A, Wikstrom AC, Okret S, Cantoni E, Gustafsson JA. Immunocytochemical studies on the localization of glucocorticoid receptor immunoreactive nerve cells in the lower brain stem and spinal cord of the male rat using a monoclonal antibody against rat liver glucocorticoid receptor. Neurosci Lett 1985; 60: 1-6.

57. Geinisman Y, Disterhoft JF, Gundersen HJ, McEchron MD, Persina IS, Power JM, van der Zee EA, West MJ. Remodeling of hippocampal synapses after hippocampus-dependent associative learning. J Comp Neurol 2000; 417: 49-59.

58. Georgotas A, McCue RE, Kim OM, Hapworth WE, Reisberg B, Stoll PM, Sinaiko E, Fanelli C, Stokes PE. Dexamethasone suppression in dementia, depression, and normal aging. Am J Psychiatry 1986; 143: 452-456.

59. Goodman Y, Bruce AJ, Cheng B, Mattson MP Estrogens attenuate and corticosterone exacerbates excitotoxicity, oxidative injury, and amyloid betapeptide toxicity in hippocampal neurons. J Neurochem 1996; 66: 1836-1844.

60. Gould E, Cameron HA. Regulation of neuronal birth, migration and death in the rat dentate gyrus. Dev Neurosci 1996; 18:22-35.

61. Gould E, Tanapat P, Rydel T, Hastings N. Regulation of hippocampal neurogenesis in adulthood. Biol Psychiatry 2000; 48: 715-720.

62. Gould E, Tanapat P. Stress and hippocampal neurogenesis. Biol Psychiatry 1999; 46: 1472-1479.

63. Gould E, Woolley C, McEwen B. Short-term glucocorticoid manipulations affect neuronal morphology and survival in the adult dentate gyrus. Neuroscience 1990; 37: 367-375.

64. Gould E, Woolley CS, Cameron HA, Daniels DC, McEwen BS. Adrenal steroids regulate postnatal development of the rat dentate gyrus: II. Effects of glucocorticoids and mineralocorticoids on cell birth. J Comp Neurol 1991; 313: 486-493.

65. Gould E, Woolley CS, McEwen BS. Adrenal steroids regulate postnatal development of the rat dentate gyrus: I. Effects of glucocorticoids on cell death. J Comp Neurol 1991; 313: 479-485.

66. Grunwald M, Busse F, Hensel A, Kruggel F, RiedelHeller S, Wolf $\mathrm{H}$, Arendt T, Gertz HJ. Correlation between cortical theta activity and hippocampal volumes in health, mild cognitive impairment, and mild dementia. J Clin Neurophysiol 2001; 18: 178-184.

67. Hansson AC, Cintra A, Belluardo N, Sommer W, Bhatnagar M, Bader M, Ganten D, Fuxe K. Gluco- and mineralocorticoid receptor-mediated regulation of neurotrophic factor gene expression in the dorsal hippocampus and the neocortex of the rat. Eur J Neurosci 2000; 12: 2918-2934.

68. Harman D. Free-radical theory of aging. Increasing the functional life span. Ann NY Acad Sci 1994; 717: 1-15.

69. Hassan AH, Patchev VK, von Rosenstiel P, Holsboer F, Almeida OFX. Plasticity of hippocampal corticosteroid receptors during aging in the rat. FASEB J 1999; 13: 115-122.

70. Hassan AH, von Rosenstiel P, Patchev VK, Holsboer F, Almeida OFX. Exacerbation of apoptosis in the dentate gyrus of the aged rat by dexamethasone and the protective role of corticosterone. Exp Neurol 1996; 140: 43-52.

71. Hastings NB, Gould E. Rapid extension of axons into the $\mathrm{CA} 3$ region by adult-generated granule cells. J Comp Neurol 1999; 413: 146-154.

72. Haynes LE, Griffiths MR, Hyde RE, Barber DJ, Mitchell IJ. Dexamethasone induces limited apoptosis and extensive sublethal damage to specific subregions of the striatum and hippocampus: implications for mood disorders. Neuroscience 2001; 104: 57-69.

73. Herman JP, Cullinan WE. Neurocircuitry of stress: central control of the hypothalamo-pituitary-adrenocortical axis. Trends Neurosci 1997; 20: 78-84.

74. Herman JP, Cullinan WE, Morano MI, Akil H, Watson SJ. Contribution of the ventral subiculum to inhibitory regulation of the hypothalamo-pituitary-adrenocortical axis. J Neuroendocrinol 1995; 7: 475-482.

75. Hollenberg SM, Weinberger C, Ong ES, Cerelli G, Oro A, Lebo R, Thompson EB, Rosenfeld MG, Evans RM. Primary structure and expression of a functional human glucocorticoid receptor cDNA. Nature $1985 ; 318$ : 635 641

76. Holsboer F. The corticosteroid receptor hypothesis of depression. Neuropsychopharmacology 2000; 23: 477501.

77. Holsboer F, Spengler D, Heuser I. The role of corticotropin-releasing hormone in the pathogenesis of Cushing's disease, anorexia nervosa, alcoholism, affective disorders and dementia. Prog Brain Res 1992; 93: 385-417.

78. Horner H, Packan D, Sapolsky R. Glucocorticoids inhibit glucose transport in cultured hippocampal neurons and glia. Neuroendocrinology 1990; 52: 57-62.

79. Hortnagl H, Berger ML, Havelec L, Hornykiewicz O. Role of glucocorticoids in the cholinergic degeneration in rat hippocampus induced by ethylcholine aziridinium (AF64A). J Neurosci 1993; 13: 2939-2945.

80. Hughes P, Dragunow M. Induction of immediate-early genes and the control of neurotransmitter-regulated gene 
expression within the nervous system. Pharmacol Rev 1995; 47: 133-178.

81. Issa AM, Rowe W, Gauthier S, Meaney MJ. Hypothalamic-pituitary-adrenal activity in aged, cognitively impaired and cognitively unimpaired rats. J Neurosci 1990; 10: 3247-3254.

82. Jacobson L, Sapolsky R. The role of the hippocampus in feedback regulation of the hypothalamic-pituitaryadrenocortical axis. Endocr Rev 1991; 12: 118-134.

83. Joels M. Corticosteroid actions in the hippocampus. J Neuroendocrinol 2001; 13: 657-669.

84. Joels M, de Kloet ER. Mineralocorticoid and glucocorticoid receptors in the brain. Implications for ion permeability and transmitter systems. Prog Neurobiol 1994; 43 : 1-36.

85. Joels M, Hesen W, de Kloet ER. Long-term control of neuronal excitability by corticosteroid hormones. J Steroid Biochem Mol Biol 1995; 53: 315-323

86. Johnson M, Stone DM, Bush LG, Hanson GR, Gibb JW. Glucocorticoids and 3,4-methylenedioxymethamphetamine (MDMA)-induced neurotoxicity. Eur J Pharmacol 1989; 161: $181-188$.

87. Kadekaro M, Ito M, Gross PM. Local cerebral glucose utilization is increased in acutely adrenalectomized rats. Neuroendocrinology 1988; 47: 329-334.

88. Kandel ES, Hay N. The regulation and activities of the multifunctional serine/threonine kinase Akt/PKB. Exp Cell Res 1999; 253: 210-229.

89. Kaplan MS, Bell DH. Neuronal proliferation in the 9month-old rodent-radioautographic study of granule cells in the hippocampus. Exp Brain Res 1983; 52: 1-5.

90. Karst H, Joels M. Calcium currents in rat dentate granule cells are altered after adrenalectomy. Eur J Neurosci 2001; 14: 503-512.

91. Karst H, Wadman WJ, Joels M. Corticosteroid receptordependent modulation of calcium currents in rat hippocampal CA1 neurons. Brain Res 1994; 649: 234-242.

92. Katzenellenbogen JA, Katzenellenbogen BS. Nuclear hormone receptors: ligand-activated regulators of transcription and diverse cell responses. Chem Biol 1996; 3 : 529-536.

93. Kennedy SG, Wagner AJ, Conzen SD, Jordan J, Bellacosa A, Tsichlis PN, Hay N. The PI 3-kinase/Akt signaling pathway delivers an anti-apoptotic signal. Genes Dev 1997; 11: 701-713.

94. Kim JJ, Yoon KS. Stress: metaplastic effects in the hippocampus. Trends Neurosci 1998; 21: 505-509.

95. Knigge K, Hays M. Evidence of inhibitive role of hippocampus in neural regulation of $\mathrm{ACTH}$ release. Proc Soc Exp Biol Med 1963; 114: 67-69.

96. Kohler C. Subicular projections to the hypothalamus and brainstem: some novel aspects revealed in the rat by the anterograde Phaseolus vulgaris leukoagglutinin (PHAL) tracing method. Prog Brain Res 1990; 83: 59-69.

97. Koide T, Wieloch TW, Siesjo BK. Chronic dexamethasone pretreatment aggravates ischemic neuronal necrosis. J Cereb Blood Flow Metab 1986; 6: 395-404.
98. Kolasa K, Song L, Jope RS. Adrenalectomy increases phosphoinositide hydrolysis induced by norepinephrine or excitatory amino acids in rat hippocampal slices. Brain Res 1992; 579: 128-134.

99. Krozowski ZS, Funder JW. Renal mineralocorticoid receptors and hippocampal corticosterone-binding species have identical intrinsic steroid specificity. Proc Natl Acad Sci USA 1983; 80: 6056-6060.

100. Kuhn HG, Dickinson-Anson H, Gage FH. Neurogenesis in the dentate gyrus of the adult rat: age-related decrease of neuronal progenitor proliferation. J Neurosci 1996; 16: 2027-2033.

101. Kuhn HG, Winkler J, Kempermann G, Thal LJ, Gage FH. Epidermal growth factor and fibroblast growth factor-2 have different effects on neural progenitors in the adult rat brain. J Neurosci 1997; 17: 5820-5829.

102. Kuroda Y, McEwen BS. Effect of chronic restraint stress and tianeptine on growth factors, growth-associated protein-43 and microtubule-associated protein $2 \mathrm{mRNA}$ expression in the rat hippocampus. Mol Brain Res 1998; 59: 35-39.

103. Landfield P, Baskin R, Pitler T. Brain-aging correlates: retardation by hormonal-pharmacological treatments. Science 1981;214: 581-584.

104. Landfield P, Eldridge JC. The glucocorticoid hypothesis of brain aging and neurodegeneration: recent modifications. Acta Endocrinol 1991; 125: 54-64.

105. Landfield P, Waymire J, Lynch G. Hippocampal aging and adrenocorticoids: a quantitative correlation. Science 1978; 202: 1098-1101.

106. Le Menuet D, Zennaro MC, Viengchareun S, Lombes M. Transgenic mouse models to study human mineralocorticoid receptor function in vivo. Kidney Int 2000; 57 : 1299-1306.

107. Leverenz JB, Wilkinson CW, Wamble M, Corbin S, Grabber JE, Raskind MA, Peskind ER. Effect of chronic high-dose exogenous cortisol on hippocampal neuronal number in aged nonhuman primates. J Neurosci 1999; 19: 2356-2361.

108. Levy A, Dachir S, Arbel I, Kadar T. Aging, stress, and cognitive function. Ann NY Acad Sci 1994; 717: 79-88.

109. Lewin GR, Barde YA. Physiology of the neurotrophins. Annu Rev Neurosci 1996; 19: 289-317.

110. Li X, Qiu J, Wang J, Zhong Y, Zhu J, Chen Y. Corticosterone-induced rapid phosphorylation of p38 and JNK mitogen-activated protein kinases in PC12 cells. FEBS Lett $2001 ; 492: 210-214$.

111. Lindholm D, Castren M, Hengerer B, Leingartner A, Castren E, Thoenen H. Glucocorticoids and neurotrophin gene regulation in the nervous system. Ann NY Acad Sci 1994; 746: 195-202.

112. Linthorst AC, Flachskamm C, Barden N, Holsboer F, Reul JM. Glucocorticoid receptor impairment alters CNS responses to a psychological stressor: an in vivo microdialysis study in transgenic mice. Eur J Neurosci 2000; 12: 283-291. 
113. Lombes M, Binart N, Delahaye F, Baulieu EE, RafestinOblin ME. Differential intracellular localization of human mineralocorticosteroid receptor on binding of agonists and antagonists. Biochem J 1994; 302: 191197.

114. Lopez-Figueroa MO, Itoi K, Watson SJ. Regulation of nitric oxide synthase messenger RNA expression in the rat hippocampus by glucocorticoids. Neuroscience 1998; 87: 439-446.

115. Lowy MT, Gault L, Yamamoto BK. Adrenalectomy attenuates stress-induced elevations in extracellular glutamate concentrations in the hippocampus. J Neurochem 1993; 61: 1957-1960.

116. Luine V, Villegas M, Martinez C, McEwen BS. Repeated stress causes reversible impairments of spatial memory performance. Brain Res 1994; 639: 167-170.

117. Lupien SJ, de Leon M, de Santi S, Convit A, Tarshish C, Nair NPV, Thakur M, McEwen BS, Hauger RL, Meaney MJ. Cortisol levels during human aging predict hippocampal atrophy and memory deficits. Nature Neurosci 1998; 1: 69-73.

118. Lupien SJ, Gaudreau S, Tchiteya BM, Maheu F, Sharma S, Nair NP, Hauger RL, McEwen BS, Meaney MJ. Stress-induced declarative memory impairment in healthy elderly subjects: relationship to cortisol reactivity. J Clin Endocrinol Metab 1997; 82: 2070-2075.

119. Maehlen J, Torvik A. Necrosis of granule cells of hippocampus in adrenocortical failure. Acta Neuropathol 1990; 80: 85-87.

120. Magarinos AM, McEwen BS. Stress-induced atrophy of apical dendrites of hippocampal CA3c neurons: comparison of stressors. Neuroscience 1995; 69: 83-88.

121. Magarinos AM, Verdugo JM, McEwen BS. Chronic stress alters synaptic terminal structure in hippocampus. Proc Natl Acad Sci USA 1997; 94: 14002-14008.

122. Maiyar AC, Phu PT, Huang AJ, Firestone GL. Repression of glucocorticoid receptor transactivation and DNA binding of a glucocorticoid response element within the serum/glucocorticoid-inducible protein kinase (sgk) gene promoter by the p53 tumor suppressor protein. Mol Endocrinol 1997; 11:312-329.

123. Makara GB, Haller J. Non-genomic effects of glucocorticoids in the neural system. Evidence, mechanisms and implications. Prog Neurobiol 2001; 65: 367-390.

124. Mangelsdorf DJ, Thummel C, Beato M, Herrlich $P$, Schutz G, Umesono K, Blumberg B, Kastner P, Mark $\mathrm{M}$, Chambon $\mathrm{P}$. The nuclear receptor superfamily: the second decade. Cell 1995; 83: 835-839.

125. Markakis EA, Gage FH. Adult-generated neurons in the dentate gyrus send axonal projections to field $\mathrm{CA} 3$ and are surrounded by synaptic vesicles. J Comp Neurol 1999; 406: 449-460.

126. Masoro EJ. Glucocorticoids and aging. Aging 1995; 7 : 407-413.

127. McAllister AK, Katz LC, Lo DC. Neurotrophins and synaptic plasticity. Annu Rev Neurosci 1999; 22: 295-318.
128. McCormick CM, McNamara M, Mukhopadhyay S, Kelsey J. Acute corticosterone replacement reinstates performance on spatial and nonspatial memory tasks 3 months after adrenalectomy despite degeneration in the dentate gyrus. Behav Neurosci 1997; 111: 518-531.

129. McEwen BS. Re-examination of the glucocorticoid hypothesis of stress and aging. Prog Brain Res 1992; 93: 365-383.

130. McEwen BS. The neurobiology of stress: from serendipity to clinical relevance. Brain Res 2000; 886: 172189.

131. McEwen BS. Stress and hippocampal plasticity. Annu Rev Neurosci 1999; 22:105-122.

132. McEwen BS. Stress and the aging hippocampus. Front Neuroendocrinol 1999; 20: 49-70.

133. McEwen BS, Biron CA, Brunson KW, Bulloch K, Chambers WH, Dhabhar FS, Goldfarb RH, Kitson RP, Miller AH, Spencer RL, Weiss JM. The role of adrenocorticoids as modulators of immune function in health and disease: neural, endocrine and immune interactions. Brain Res Rev 1997; 23: 79-133.

134. McEwen BS, de Kloet ER, Rostene W. Adrenal steroid receptors and actions in the nervous system. Physiol Rev 1986; 66: 1121-1188.

135. McEwen BS, Sapolsky RM. Stress and cognitive function. Curr Opin Neurobiol 1995; 5: 205-216.

136. McEwen BS, Weiss JM, Schwartz LS. Selective retention of corticosterone by limbic structures in rat brain. Nature 1968; 220: 911-912.

137. McIntosh LM, Cortopassi KM, Sapolsky R. Glucocorticoids may alter antioxidant enzyme capacity in the brain: kainic acid studies. Brain Res 1998; 791: 215-222.

138. McIntosh LM, Hong KE, Sapolsky R. Glucocorticoids may alter antioxidant enzyme capacity in the brain: baseline studies. Brain Res 1998; 791: 209-214.

139. McIntosh LM, Sapolsky R. Glucocorticoids increase the accumulation of reactive oxygen species and enhance adriamycin-induced toxicity in neuronal cultures. Exp Neurol 1996; 141: 201-206.

140. Miller FD, Kaplan DR. Neurotrophin signalling pathways regulating neuronal apoptosis. Cell Mol Life Sci 2001; 58: 1045-1053.

141. Miller MM, Antecka E, Sapolsky R. Short term effects of glucocorticoids upon hippocampal ultrastructure. Exp Brain Res 1989; 77: 309-314.

142. Miyashita T, Krajewski S, Krajewska M, Wang HG, Lin HK, Liebermann DA, Hoffman B, Reed JC. Tumor suppressor p53 is a regulator of bcl-2 and bax gene expression in vitro and in vivo. Oncogene 1994; 9: 1799-1805.

143. Miyashita T, Reed JC. Tumor suppressor p53 is a direct transcriptional activator of the human bax gene. Cell 1995; 80: 293-299.

144. Mizoguchi K, Kunishita T, Chui DH, Tabira T. Stress induces neuronal death in the hippocampus of castrated rats. Neurosci Lett 1992; 138: 157-160. 
145. Moghaddam B, Bolinao ML, Stein-Behrens B, Sapolsky R. Glucocorticoids mediate the stress-induced extracellular accumulation of glutamate. Brain Res 1994; 655: 251-254.

146. Morano MI, Vazquez DM, Akil H. The role of the hippocampal mineralocorticoid and glucocorticoid receptors in the hypothalamo-pituitary-adrenal axis of the aged Fisher rat. Mol Cell Neurosci 1994; 5: 400-412.

147. Morimoto M, Morita N, Ozawa H, Yokoyama K, Kawata M. Distribution of glucocorticoid receptor immunoreactivity and mRNA in the rat brain: an immunohistochemical and in situ hybridization study. Neurosci Res 1996; 26: 235-269.

148. Morrione A, Navarro M, Romano G, Dews M, Reiss K, Valentinis B, Belletti B, Baserga R. The role of the insulin receptor substrate- 1 in the differentiation of rat hippocampal neuronal cells. Oncogene 2001; 20: 48424852.

149. Moser MB, Trommald M, Andersen P. An increase in dendritic spine density on hippocampal CA1 pyramidal cells following spatial learning in adult rats suggests the formation of new synapses. Proc Natl Acad Sci USA 1994; 91: 12673-12675.

150. Munck A, Guyre PM, Holbrook NJ. Physiological functions of glucocorticoids in stress and their relation to pharmacological actions. Endocr Rev 1984; 5: 25-44.

151. Newcomer JW, Selke G, Melson AK, Hershey T, Craft $\mathrm{S}$, Richards $\mathrm{K}$, Alderson AL. Decreased memory performance in healthy humans induced by stress-level cortisol treatment. Arch Gen Psychiatry 1999; 56: 527533.

152. Nitta A, Fukumitsu H, Kataoka H, Nomoto H, Furukawa S. Administration of corticosterone alters intracellular localization of brain-derived neurotrophic factor-like immunoreactivity in the rat brain. Neurosci Lett 1997; 226: 115-118.

153. O'Brien JT, Schweitzer I, Ames D, Tuckwell V, Mastwyk M. Cortisol suppression by dexamethasone in the healthy elderly: effects of age, dexamethasone levels, and cognitive function. Biol Psychiatry 1994; 36: 389394.

154. Odermatt A, Arnold P, Frey FJ. The intracellular localization of the mineralocorticoid receptor is regulated by 1 lbeta-hydroxysteroid dehydrogenase type 2. J Biol Chem 2001; 276: 28484-28492.

155. Oitzl MS, de Kloet ER, Joels M, Schmid W, Cole TJ. Spatial learning deficits in mice with a targeted glucocorticoid receptor gene disruption. Eur J Neurosci 1997; 9: 2284-2296.

156. Oitzl MS, Fluttert M, de Kloet ER. The effect of corticosterone on reactivity to spatial novelty is mediated by central mineralocorticosteroid receptors. Eur J Neurosci 1994; 6: 1072-1079.

157. Oitzl MS, Josephy M, Spruijt BM. An ACTH/MSH(4-9) analog counteracts the behavioral effects of a mineralocorticoid receptor antagonist. Pharmacol Biochem Behav 1993; 44: 447-450.
158. O'Kusky JR, Ye P, D'Ercole AJ. Insulin-like growth factor-I promotes neurogenesis and synaptogenesis in the hippocampal dentate gyrus during postnatal development. J Neurosci 2000; 20: 8435-8442.

159. Olivenza R, Moro MA, Lizasoain I, Lorenzo P, Fernandez AP, Rodrigo J, Bosca L, Leza JC. Chronic stress induces the expression of inducible nitric oxide synthase in rat brain cortex. J Neurochem 2000; 74 : 785 791.

160. O'Malley A, O'Connell C, Murphy KJ, Regan CM. Transient spine density increases in the mid-molecular layer of hippocampal dentate gyrus accompany consolidation of a spatial learning task in the rodent. Neuroscience 2000; 99: 229-232.

161. Patel PD, Sherman TG, Goldman DJ, Watson SJ. Molecular cloning of a mineralocorticoid (type I) receptor complementary DNA from rat hippocampus. Mol Endocrinol 1989; 3: 1877-1885.

162. Pavlides C, Ogawa S, Kimura A, McEwen BS. Role of adrenal steroid mineralocorticoid and glucocorticoid receptors in long-term potentiation in the $\mathrm{CA} 1$ field of hippocampal slices. Brain Res 1996; 738: 229-235.

163. Plaschke K, Muller D, Hoyer S. Effect of adrenalectomy and corticosterone substitution on glucose and glycogen metabolism in rat brain. J Neural Transm 1996; 103: 89100.

164. Pratt WB, Toft DO. Steroid receptor interactions with heat shock protein and immunophilin chaperones. Endocr Rev 1997; 18: 306-360.

165. Qiao X, Hughes PE, Venero JL, Dugich-Djordjevic MM, Nichols NR, Hefti F, Knusel B. NT-4/5 protects against adrenalectomy-induced apoptosis of rat hippocampal granule cells. NeuroReport 1996; 7: 682-686.

166. Rajan V, Edwards CR, Seckl JR. 11ß-hydroxysteroid dehydrogenase in cultured hippocampal cells reactivates inert 11-dehydrocorticosterone, potentiating neurotoxicity. J Neurosci 1996; 16:65-70.

167. Ramón Y Cajal S. Neue Darstellung vom histologischen Bau des Centralnervensystem. Arch Anat Physiol 1893; 319-428.

168. Reagan LP, Magarinos AM, Lucas LR, van Bueren A, McCall AL, McEwen BS. Regulation of GLUT-3 glucose transporter in the hippocampus of diabetic rats subjected to stress. Am J Physiol 1999; 276: E879-886.

169. Reagan LP, Magarinos AM, Yee DK, Swzeda LI, Van Bueren A, McCall AL, McEwen BS. Oxidative stress and HNE conjugation of GLUT3 are increased in the hippocampus of diabetic rats subjected to stress. Brain Res 2000; 862: 292-300.

170. Reagan LP, McEwen BS. Controversies surrounding glucocorticoid-mediated cell death in the hippocampus. J Chem Neuroanat 1997; 13: 149-167.

171. Reagan LP, McKittrick CR, McEwen BS. Corticosterone and phenytoin reduce neuronal nitric oxide synthase messenger RNA expression in rat hippocampus. Neuroscience 1999; 91: 211-219. 
172. Reichardt HM, Tronche F, Berger S, Kellendonk C, Schutz G. New insights into glucocorticoid and mineralocorticoid signaling: lessons from gene targeting. Adv Pharmacol 2000; 47: 1-21

173. Reiman EM, Uecker A, Caselli RJ, Lewis S, Bandy D, de Leon MJ, De Santi S, Convit A, Osborne D, Weaver A, Thibodeau SN. Hippocampal volumes in cognitively normal persons at genetic risk for Alzheimer's disease. Ann Neurol 1998; 44: 288-291.

174. Reul JM, de Kloet ER. Two receptor systems for corticosterone in rat brain: microdistribution and differential occupation. Endocrinology 1985; 117: 25052511.

175. Rey M, Carlier E, Talmi M, Soumireu-Mourat B. Corticosterone effects on long-term potentiation in mouse hippocampal slices. Neuroendocrinology 1994; 60: 36-41.

176. Riva MA, Fumagalli F, Racagni G. Opposite regulation of basic fibroblast growth factor and nerve growth factor gene expression in rat cortical astrocytes following dexamethasone treatment. J Neurochem 1995; 64: 25262533.

177. Rusakov DA, Davies HA, Harrison E, Diana G, RichterLevin G, Bliss TV, Stewart MG. Ultrastructural synaptic correlates of spatial learning in rat hippocampus. Neuroscience 1997; 80: 69-77.

178. Sakhi S, Gilmore W, Tran ND, Schreiber SS. p53deficient mice are protected against adrenalectomyinduced apoptosis. NeuroReport 1996; 8: 233-235.

179. Sandi C, Loscertales M, Guaza C. Experience-dependent facilitating effect of corticosterone on spatial memory formation in the water maze. Eur J Neurosci 1997; 9: 637-642.

180. Sandi C, Rose SP. Corticosteroid receptor antagonists are amnestic for passive avoidance learning in day-old chicks. Eur J Neurosci 1994; 6: 1292-1297.

181. Sapolsky R. Do glucocorticoid concentrations rise with age in the rat? Neurobiol Aging 1992; 13: 171-174.

182. Sapolsky R. Glucocorticoids, stress and exacerbation of excitotoxic neuron death. Semin Neurosci 1994; 6: 323331.

183. Sapolsky R. Stress, glucocorticoids, and damage to the nervous system: the current state of confusion. Stress 1996; 1: 1-19.

184. Sapolsky RM. Why stress is bad for your brain. Science 1996; 273: 749-750.

185. Sapolsky RM, Krey LC, McEwen BS. Corticosterone receptors decline in a site-specific manner in the aged rat brain. Brain Res 1983; 289: 235-240.

186. Sapolsky R, Krey L, McEwen B. Prolonged glucocorticoid exposure reduces hippocampal neuron number: implications for aging. J Neurosci 1985; 5: 1221-1227.

187. Sapolsky R, Krey L, McEwen B. The neuroendocrinology of stress and aging: the glucocorticoid cascade hypothesis. Endocr Rev 1986; 7: 284-301.

188. Sapolsky RM, Pulsinelli WA. Glucocorticoids potentiate ischemic injury to neurons: therapeutic implications.
Science 1985;229: 1397-1400.

189. Schaaf MJ, de Kloet ER, Vreugdenhil E. Corticosterone effects on BDNF expression in the hippocampus. Implications for memory formation. Stress $2000 ; 3: 201$ 208.

190. Schaaf MJ, Hoetelmans RW, de Kloet ER, Vreugdenhil E. Corticosterone regulates expression of BDNF and trkB but not NT-3 and trkC mRNA in the rat hippocampus. J Neurosci Res 1997; 48: 334-341.

191. Schreiber SS, Sakhi S, Dugich-Djordjevic MM, Nichols NR. Tumor suppressor p53 induction and DNA damage in hippocampal granule cells after adrenalectomy. Exp Neurol 1994; 130: 368-376.

192. Seckl JR, Walker BR. Minireview: 11ß-hydroxysteroid dehydrogenase type 1 - a tissue-specific amplifier of glucocorticoid action. Endocrinology 2001; 142: 13711376.

193. Selye H. Confusion and controversy in the stress field. J Hum Stress 1975; 1: 37-44.

194. Sengupta S, Vonesch JL, Waltzinger C, Zheng H, Wasylyk B. Negative cross-talk between p53 and the glucocorticoid receptor and its role in neuroblastoma cells. EMBO J 2000; 19: 6051-6064.

195. Sheline YI, Wang PW, Gado MH, Csernansky JG, Vannier MW. Hippocampal atrophy in recurrent major depression. Proc Natl Acad Sci USA 1996; 93: 39083913.

196. Shors TJ, Miesegaes G, Beylin A, Zhao M, Rydel T, Gould E. Neurogenesis in the adult is involved in the formation of trace memories. Nature $2001 ; 410$ : 372376.

197. Sloviter R, Sollas A, Dean E, Neubort S. Adrenalectomy-induced granule cell degeneration in the rat hippocampal dentate gyrus: characterization of an in vitro model of controlled neuronal death. J Comp Neurol 1993; 330: 324-336.

198. Sloviter R, Valiquette G, Abrams G, Rink E, Sollas A, Paul L, Neubort S. Selective loss of hippocampal granule cells in the mature rat brain after adrenalectomy. Science 1989; 243: 535-538.

199. Smith MA, Makino S, Kvetnansky R, Post RM. Stress and glucocorticoids affect the expression of brainderived neurotrophic factor and neurotrophin-3 mRNAs in the hippocampus. J Neurosci 1995; 15: 1768-1777.

200. Sonino N, Fava GA. Psychiatric disorders associated with Cushing's syndrome. Epidemiology, pathophysiology and treatment. CNS Drugs 2001; 15:361-373.

201. Sousa N, Almeida OFX, Holsboer F, Paula-Barbosa MM, Madeira MD. Maintenance of hippocampal cell numbers in young and aged rats submitted to chronic unpredictable stress. Comparison with the effects of corticosterone treatment. Stress 1998; 2: 237-249.

202. Sousa N, Lukoyanov NV, Madeira MD, Almeida OFX, Paula-Barbosa MM. Reorganization of the morphology of hippocampal neurites and synapses after stressinduced damage correlates with behavioral improvement. Neuroscience 2000; 97: 253-266. 
203. Sousa N, Madeira MD, Paula-Barbosa MM. Corticosterone replacement restores normal morphological features to the hippocampal dendrites, axons and synapses of adrenalectomized rats. J Neurocytol 1999; 28: $541-558$.

204. Sousa N, Paula-Barbosa MM, Almeida OFX. Ligand and subfield specificity of corticoid-induced neuronal loss in the rat hippocampal formation. Neuroscience 1999; 89: 1079-1087.

205. Sousa N, Paula-Barbosa MM, Madeira MD. Effects of corticosterone treatment and rehabilitation on the hippocampal formation of neonatal and adult rats. An unbiased stereological study. Brain Res 1998; 794: 199210 .

206. Stanfield BB, Trice JE. Evidence that granule cells generated in the dentate gyrus of adult rats extend axonal projections. Exp Brain Res 1988; 72: 399-406.

207. Starkman M, Gebarski S, Berent S, Schteingart D. Hippocampal formation volume, memory dysfunction, and cortisol levels in patients with Cushing's syndrome. Biol Psychiatry 1992; 32: 756-765.

208. Starkman M, Giordani B, Gebarski S, Berent S, Schork MA, Schteingart DE. Decrease in cortisol reverses human hippocampal atrophy following treatment of Cushing's disease. Biol Psychiatry 1999; 46: 1595-1602.

209. Stein-Behrens B, Elliott EM, Miller CA, Schilling JW, Newcombe R, Sapolsky RM. Glucocorticoids exacerbate kainic acid-induced extracellular accumulation of excitatory amino acids in the rat hippocampus. J Neurochem 1992; 58: 1730-1735.

210. Stein-Behrens B, Lin W, Sapolsky R. Physiological elevations of glucocorticoids potentiate glutamate accumulation in the hippocampus. J Neurochem 1994; 63: 596-603.

211. Thoenen H. Neurotrophins and neuronal plasticity. Science 1995; 270: 593-598.

212. Tombaugh GC, Sapolsky RM. Corticosterone accelerates hypoxia- and cyanide-induced ATP loss in cultured hippocampal astrocytes. Brain Res 1992; 588: 154-158.

213. Trapp T, Holsboer F. Heterodimerization between mineralocorticoid and glucocorticoid receptors increases the functional diversity of corticosteroid action. Trends Pharmacol Sci 1996; 17: 145-149.

214. Trapp T, Rupprecht R, Castren M, Reul JM, Holsboer F. Heterodimerization between mineralocorticoid and glucocorticoid receptor: a new principle of glucocorticoid action in the CNS. Neuron 1994; 13: 1457-1462.

215. Trejo JL, Carro E, Torres-Aleman I. Circulating insulinlike growth factor I mediates exercise-induced increases in the number of new neurons in the adult hippocampus. J Neurosci 2001; 21: 1628-1634.

216. Truss M, Beato M. Steroid hormone receptors: interaction with deoxyribonucleic acid and transcription factors. Endocr Rev 1993; 14: 459-479.

217. Ueyama T, Kawai Y, Nemoto K, Sekimoto M, Tone S, Senba E. Immobilization stress reduced the expression of neurotrophins and their receptors in the rat brain. Neurosci Res 1997; 28: 103-110.

218. Unlap T, Jope RS. Dexamethasone attenuates kainateinduced AP-1 activation in rat brain. Mol Brain Res $1994 ; 24: 275-282$.

219. Unlap T, Jope RS. Dexamethasone attenuates NF-kB DNA binding activity without inducing IkB levels in rat brain in vitro. Mol Brain Res 1997; 45: 83-89.

220. Unlap T, Jope RS. Inhibition of NFkB DNA binding activity by glucocorticoids in rat brain. Neurosci Lett 1995; 198: 41-44.

221. Uno H, Tarara R, Else J, Suleman M, Sapolsky R. Hippocampal damage associated with prolonged and fatal stress in primates. J Neurosci 1989; 9: 1705-1712.

222. Van Eekelen JA, Jiang W, de Kloet ER, Bohn MC Distribution of the mineralocorticoid and the glucocorticoid receptor mRNAs in the rat hippocampus. J Neurosci Res 1988; 21: 88-94.

223. Van Eekelen JA, Rots NY, Sutanto W, de Kloet ER. The effect of aging on stress responsiveness and central corticosteroid receptors in the brown Norway rat. Neurobiol Aging 1992; 13: 159-170.

224. Van Kampen M, Fuchs E. Age-related levels of urinary free cortisol in the tree shrew. Neurobiol Aging 1998; 19:363-366.

225. Van Reempts J, Dikova M, Werbrouck L, Clincke G, Borgers M. Synaptic plasticity in rat hippocampus associated with learning. Behav Brain Res 1992; 51: 179-183.

226. Virgin CE Jr, Ha TP, Packan DR, Tombaugh GC, Yang SH, Horner HC, Sapolsky RM. Glucocorticoids inhibit glucose transport and glutamate uptake in hippocampal astrocytes: implications for glucocorticoid neurotoxicity. J Neurochem 1991; 57: 1422-1428.

227. Vollmann-Honsdorf GK, Flugge G, Fuchs E. Chronic psychosocial stress does not affect the number of pyramidal neurons in tree shrew hippocampus. Neurosci Lett 1997; 233: 121-124.

228. Vreugdenhil E, de Kloet ER, Schaaf M, Datson NA. Genetic dissection of corticosterone receptor function in the rat hippocampus. Eur Neuropsychopharmacol 2001; 11: 423-430.

229. Watanabe Y, Gould E, Daniels DC, Cameron H, McEwen BS. Tianeptine attenuates stress-induced morphological changes in the hippocampus. Eur $\mathrm{J}$ Pharmacol 1992; 222: 157-162

230. Watanabe Y, Gould E, McEwen BS. Stress induces atrophy of apical dendrites of hippocampal CA3 pyramidal neurons. Brain Res 1992; 588: 341-345.

231. Watanabe Y, Weiland NG, McEwen BS. Effects of adrenal steroid manipulations and repeated restraint stress on dynorphin mRNA levels and excitatory amino acid receptor binding in hippocampus. Brain Res 1995; 680: 217-225.

232. Weiland NG, Orchinik M, Tanapat P. Chronic corticosterone treatment induces parallel changes in $\mathrm{N}$-methylD-aspartate receptor subunit messenger RNA levels and 
antagonist binding sites in the hippocampus. Neuroscience 1997; 78: 653-662.

233. Wenzel J, Kammerer E, Kirsche W, Matthies H, Wenzel M. Electron microscopic and morphometric studies on synaptic plasticity in the hippocampus of the rat following conditioning. J Hirnforsch 1980; 21: 647-654.

234. Whitnall MH. Regulation of the hypothalamic corticotropin-releasing hormone neurosecretory system. Prog Neurobiol 1993, 40: 573-629.

235. Wolkowitz OM, Reus VI, Canick J, Levin B, Lupien SJ. Glucocorticoid medication, memory and steroid psychosis in medical illness. Ann NY Acad Sci 1997; 823: 81-96.

236. Woolley CS, Gould E, McEwen BS. Exposure to excess glucocorticoids alters dendritic morphology of adult hippocampal pyramidal neurons. Brain Res 1990; 531: 225-231.

237. Woolley CS, Gould E, Sakai R, Spencer R, McEwen B. Effects of aldosterone or RU28362 treatment on adrenalectomy-induced cell death in the dentate gyrus in the adult rat. Brain Res 1991; 554: 312-315.

238. Yehuda R. Biology of posttraumatic stress disorder. J Clin Psychiatry 2001; 62: 41-46.

239. Yehuda R. Linking the neuroendocrinology of posttraumatic stress disorder with recent neuroanatomic findings. Semin Clin Neuropsychiatry 1999; 4: 256-265.

240. Yu C, Yap N, Chen D, Cheng S. Modulation of hormonedependent transcriptional activity of the glucocorticoid receptor by the tumor suppressor p53. Cancer Lett 1997; 116: 191-196.

241. Yu VC, Naar AM, Rosenfeld MG. Transcriptional regulation by the nuclear receptor superfamily. Curr Opin Biotechnol 1992; 3: 597-602.

242. Yusim A, Franklin L, Brooke S, Ajilore O, Sapolsky R. Glucocorticoids exacerbate the deleterious effects of gp120 in hippocampal and cortical explants. J Neurochem 2000; 74: 1000-1007. 